\title{
Wildfire influences on the variability and trend of summer surface ozone in the mountainous western United States
}

\author{
Xiao Lu ${ }^{1}$, Lin Zhang ${ }^{1}$, Xu Yue ${ }^{2}$, Jiachen Zhang ${ }^{3}$, Daniel A. Jaffe ${ }^{4,5}$, Andreas Stohl ${ }^{6}$, Yuanhong Zhao ${ }^{1}$, and \\ Jingyuan Shao ${ }^{1}$ \\ ${ }^{1}$ Laboratory for Climate and Ocean-Atmosphere Sciences, Department of Atmospheric and Oceanic Sciences, \\ School of Physics, Peking University, Beijing 100871, China \\ ${ }^{2}$ Climate Change Research Center, Institute of Atmospheric Physics, Chinese Academy of Sciences, Beijing 100029, China \\ ${ }^{3}$ Department of Civil and Environmental Engineering, Viterbi School of Engineering, University of Southern California, \\ Los Angeles, CA 90089, USA \\ ${ }^{4}$ School of Science, Technology, Engineering and Math, University of Washington Bothell, Bothell, WA 98011, USA \\ ${ }^{5}$ Department of Atmospheric Sciences, University of Washington, Seattle, WA 98195, USA \\ ${ }^{6}$ Norwegian Institute for Air Research, 2007 Kjeller, Norway
}

Correspondence to: Lin Zhang (zhanglg@pku.edu.cn)

Received: 19 July 2016 - Published in Atmos. Chem. Phys. Discuss.: 26 July 2016

Revised: 6 November 2016 - Accepted: 9 November 2016 - Published: 24 November 2016

\begin{abstract}
Increasing wildfire activities in the mountainous western US may present a challenge for the region to attain a recently revised ozone air quality standard in summer. Using current Eulerian chemical transport models to examine the wildfire ozone influences is difficult due to uncertainties in fire emissions, inadequate model chemistry, and resolution. Here we quantify the wildfire influence on the ozone variability, trends, and number of high MDA8 (daily maximum $8 \mathrm{~h}$ average) ozone days over this region in summers (June, July, and August) 1989-2010 using a new approach. We define a fire index using retroplumes (plumes of back-trajectory particles) computed by a Lagrangian dispersion model (FLEXPART) and develop statistical models based on the fire index and meteorological parameters to interpret MDA8 ozone concentrations measured at 13 Intermountain West surface sites. We show that the statistical models are able to capture the ozone enhancements by wildfires and give results with some features different from the GEOS-Chem Eulerian chemical transport model. Wildfires enhance the Intermountain West regional summer mean MDA8 ozone by $0.3-$ $1.5 \mathrm{ppbv}$ (daily episodic enhancements reach 10-20 ppbv at individual sites) with large interannual variability, which are strongly correlated with the total MDA8 ozone. We find large fire impacts on the number of exceedance days; for the 13 CASTNet sites, $31 \%$ of the summer days with MDA8 ozone
\end{abstract}

exceeding 70 ppbv would not occur in the absence of wildfires.

\section{Introduction}

Ozone is a secondary air pollutant that exerts negative effects on human health and vegetation, and is also a shortlived greenhouse gas with a positive radiative forcing of 0.40 (0.20 to 0.60$) \mathrm{W} \mathrm{m}^{-2}$ (Shindell et al., 2013; Stevenson et al., 2013; Stocker et al., 2013; Cooper et al., 2014; Monks et al., 2015). Tropospheric ozone is generated through sunlight-driven chemical oxidation of $\mathrm{CO}, \mathrm{CH}_{4}$, and other non-methane volatile organic compounds (NMVOCs) in the presence of nitrogen oxides $\left(\mathrm{NO}_{x}=\mathrm{NO}+\mathrm{NO}_{2}\right)$. It can also be transported from the stratosphere. In October 2015, the US Environmental Protection Agency (EPA) lowered the National Ambient Air Quality Standard (NAAQS) for ozone, defined as the annual fourth-highest daily maximum $8 \mathrm{~h}$ average (MDA8) concentration averaged over 3 years, from 75 to 70 ppbv (US EPA, 2015). Attaining this lower ozone air quality standard places new challenges for the US states (Cooper et al., 2015).

Ozone over the mountainous western US (US Intermountain West), extending between the Sierra Nevada/Cascades to 
the west and the Rocky Mountains in the east, has recently drawn an increasing attention (Cooper et al., 2015; Lin et al., 2015a). Unlike in the eastern US, where $\mathrm{NO}_{x}$ emission controls have led to ozone declines, surface ozone concentrations in the Intermountain West have been increasing in the 1990-2010 period most likely caused by rising background ozone (Jaffe et al., 2007; Cooper et al., 2012; Lin et al., 2015a), although recent research suggests that these trends flatten out or even reverse in the later decade (2000-2010) (Cooper et al., 2014; Simon et al., 2015; Strode et al., 2015). The North American background ozone, defined by the US EPA as the surface ozone concentration that would be present over the US in the absence of anthropogenic emissions from North America (US EPA, 2006), is particularly high in the Intermountain West due to high elevation, arid landscape, and frequent large-scale air subsidence (Fiore et al., 2002; McDonald-Buller et al., 2011; Zhang et al., 2011; Emery et al., 2012; Dolwick et al, 2015). The background ozone includes ozone contributed by anthropogenic emissions outside North America, e.g., over Asia and Europe (Zhang et al., 2009; Cooper et al., 2010; Lin et al., 2012a), as well as natural sources such as lightning (Mueller et al., 2011; Zhang et al., 2014), wildfires (Jaffe et al., 2008, 2013; Mueller et al., 2011; Zhang et al., 2014), and stratospheric influxes (Lin et al., 2012b, 2015b; Zhang et al., 2014). A number of studies have shown that model simulations considering rising Asian emissions and global methane can only explain part of the observed increasing ozone trends in the western US (Fiore et al., 2009; Koumoutsaris et al., 2012; Parrish et al., 2014).

Wildfires are potentially important sources of background ozone, as they emit large amounts of $\mathrm{NO}_{x}, \mathrm{CO}$, and NMVOCs particularly in summer under hot and dry weather conditions conducive to ozone formation. There is evidence that the frequency and intensity of wildfires in the western US have been increasing from 1970s to 2005 driven by increasing temperatures and earlier snowmelt (Westerling et al., 2006). The number of high-ozone days is shown to have a strong interannual correlation with wildfire burned area over this region (Jaffe et al., 2008; Jaffe and Wigder 2012). However, quantifying ozone production in wildfire plumes is complicated by various uncertainties including those in wildfire emissions, chemical reactions, and variations in meteorology such as changes in temperature (Jaffe and Wigder, 2012). Fire emissions of ozone precursors vary significantly among different ecosystem types, biomass nitrogen loads, and combustion efficiency (Andreae et al., 2001; Akagi et al., 2011). Ozone chemistry in fire plumes shows strong nonlinearity with observations of ozone over $\mathrm{CO}$ enhancements $\left(\Delta \mathrm{O}_{3} / \Delta \mathrm{CO}\right)$ in fire plumes ranging from -0.1 to $0.9 \mathrm{ppbv} \mathrm{ppbv}^{-1}$, depending on plume ages, aerosol effects, and mixing with urban emissions (Real et al., 2007; Jaffe and Wigder 2012; Singh et al., 2012; Parrington et al., 2013; Baylon et al., 2014). Previous studies also suggested that rapid conversion of $\mathrm{NO}_{x}$ to peroxyacetyl nitrate (PAN) would limit ozone production near the fires (especially at low tempera- tures), but decomposition of PAN could lead to additional ozone production further downwind of the fires (Alvarado et al., 2010; Jaffe et al., 2013).

A standard approach to quantify the influence of a particular source on ozone concentrations is provided by chemical transport models (CTMs) using the differences between model simulations with and without this source. This Eulerian approach has been applied in numerous studies to examine ozone from different sources based on global and regional CTMs (Pfister et al., 2007; Alvarado et al., 2010; Grell et al., 2011; Jiang et al., 2012; Zhang et al., 2014). However, application of this approach to assess wildfire ozone influences in the US Intermountain West is particularly challenging due to uncertainties in wildfire emissions and model chemistry as well as limited model resolution (Zhang et al., 2014). Our current understanding of wildfire influences on the variability and long-term trends of surface ozone is rather limited (Jaffe and Wigder 2012; Fiore et al., 2014).

In this study, we propose a new approach to estimate the influence of wildfires on surface ozone concentrations in the US Intermountain West. We define a fire index (FI) using the retroplumes (plumes of back-trajectory particles) calculated by a Lagrangian particle dispersion model (FLEXPART) combined with a daily high-resolution wildfire burned area dataset. We then develop multiple linear regression (MLR) models to estimate surface ozone concentration as a function of the FI and other meteorological parameters, which allow us to separate the influences of wildfires and meteorology. We apply this approach to interpret surface ozone concentrations measured at CASTNet (the Clean Air Status and Trends Network) sites in the US Intermountain West during the summers (June, July, and August) 1989-2010 and to quantify wildfire influences on the ozone interannual variability, trends, and exceedance days (MDA8 ozone $>70 \mathrm{ppbv}$ ) over this region. The Lagrangian-based wildfire ozone influences are also compared with those estimated by a Eulerian model (GEOS-Chem) to evaluate the consistency and difference between the two.

\section{Materials and methods}

\subsection{Data description}

We use measurements of ozone, organic carbon (OC) aerosols, meteorological parameters, and wildfire burned area data at daily temporal resolution. Hourly measurements of ozone as well as meteorological parameters including surface temperature, wind speed, relative humidity (RH), and solar radiation are accessed from CASTNet, a long-term monitoring network established to assess the trends in air pollution and acid deposition due to emission regulations (CASTNet, 2015). We focus on measurements at 13 CASTNet sites in the US Intermountain West for 1989-2010 (Fig. 1 and Table 2). Most CASTNet sites have ozone measurements 

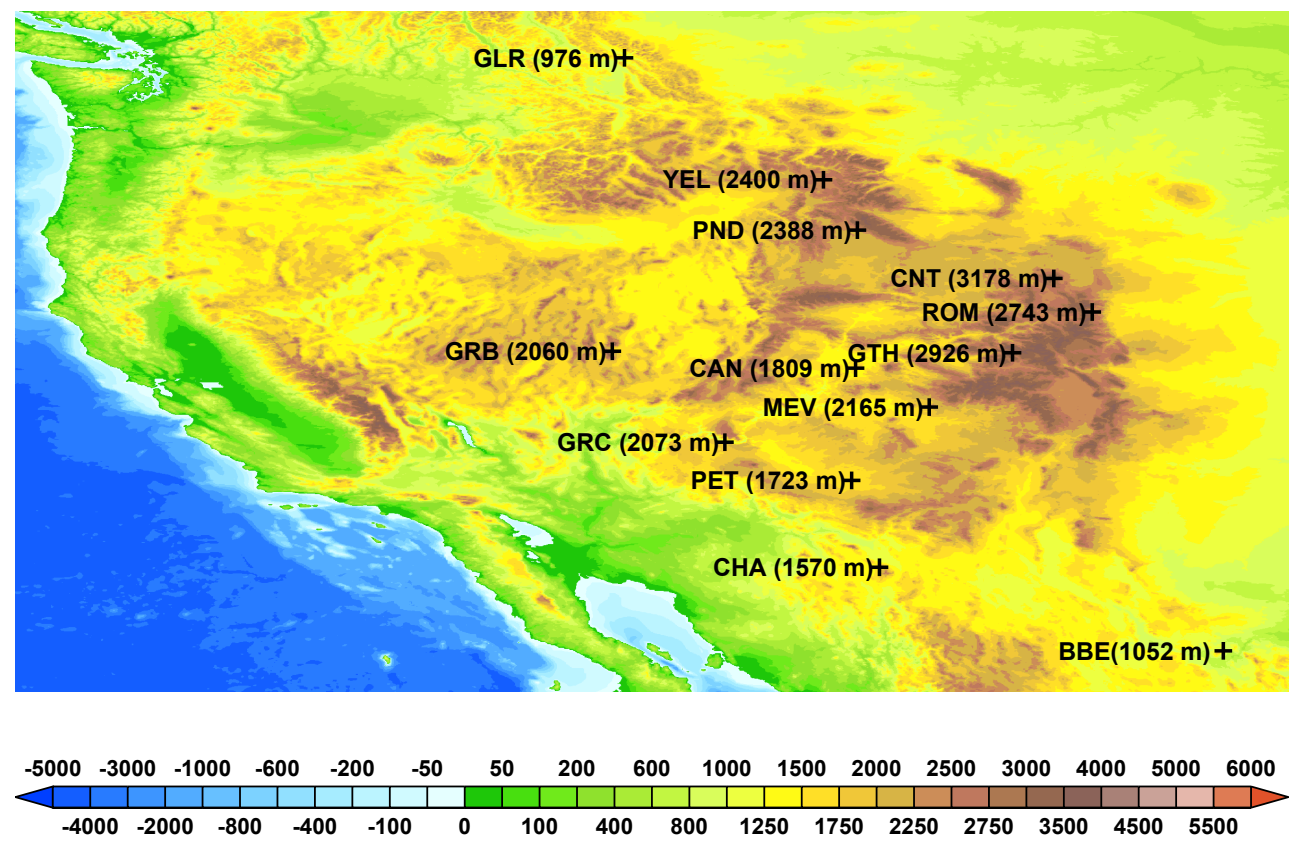

Figure 1. Thirteen CASTNet ozone monitoring sites (Table 2, black pluses) in the US Intermountain West used in this study. Also shown is SLC (Salt Lake City, Utah) urban site (filled triangle). Altitudes of the sites are also labeled. The underlying figure shows terrain elevations (m) of the western US.

for the 22-year period except for (since 1995) Mesa Verde National Park (NP) (MEV), Great Basin NP (GRB), Canyonlands NP (CAN), Big Bend NP (BBE), and (since 2003) Petrified Forest (PET). The Yellowstone NP (YEL) site experienced monitor relocation in 1996, and we access the 19891995 measurements at the earlier YEL site from the National Park Service (NPS) following Jaffe et al. (2007) and Cooper et al. (2012).

In addition, we use hourly ozone measurements from 1990 to 2010 at the Salt Lake City (SLC; $40.6^{\circ} \mathrm{N}, 111.9^{\circ} \mathrm{W}$; $1300 \mathrm{~m}$ ) urban site (Air Quality System, 2015) for comparison with the CASTNet background sites and the previous work of Jaffe et al. (2013). Measurements of OC aerosol are from collocated sites of the Interagency Monitoring of Protected Visual Environments (IMPROVE, 2015). OC aerosol concentrations are $24 \mathrm{~h}$ averages measured every 3 days.

We also use the daily wildfire burned area data over North America for 1989-2010 developed by Yue et al. (2013) that has a $0.5^{\circ} \times 0.5^{\circ}$ horizontal resolution. This inventory is constructed using the inter-agency fire reports from the national Fire and Aviation Management Web application system (FAMWEB, 2014) and applied with a daily scaling factor for the duration of each fire event based on local meteorological variables (Yue et al., 2013). The total areas burned in the Intermountain West range from 90000 to 2000000 hectares (ha) in the summers 1989-2010 with a large spatial and interannual variability. This wildfire burned area inventory has been used in Zhang et al. (2014) and was able to capture the episodic enhancements of OC aerosol concentra- tions measured in the Intermountain West for the summers 2006-2008.

\subsection{Fire index calculation with the FLEXPART model}

Jaffe et al. (2008) previously identified the impacts of wildfires on ozone at a measurement site using values of monthly wildfire burned area or carbon burned within a certain region around the site (e.g., $10^{\circ} \times 10^{\circ}$ or $5^{\circ} \times 5^{\circ}$ ). This fire indicator generally ignores the variable influence of transport of fire plumes to the site. For instance, a fire downwind of the measurement site, even one burning in the immediate vicinity, would not influence the site. Here we propose a new fire indicator using 5-day retroplumes simulated by the FLEXPART Lagrangian particle dispersion model and the daily wildfire burned area inventory mentioned above. A retroplume consists of a large number of back-trajectory particles that are released from a particular receptor location (Cooper et al., 2005). We use FLEXPART version 8.02, which is first described by Stohl et al. (2005) and has been applied to examine transport of ozone (Cooper et al., 2010) and radionuclides across the Pacific Ocean (Stohl et al., 2012). FLEXPART simulates the long-range and mesoscale transport, diffusion, and dry and wet deposition of gases or particles (Stohl et al., 2005). It is driven by the National Center for Environmental Prediction (NCEP) Climate Forecast System Reanalysis data (NCEP CFSR, 2014) with 1-hour temporal resolution, $0.5^{\circ} \times 0.5^{\circ}$ horizontal resolution, and 37 vertical levels extending from the surface to $1 \mathrm{hPa}$. 
Table 1. Variables used in the MLR models.

\begin{tabular}{|c|c|c|}
\hline Variable & Predictors used in MLR model ${ }^{\mathrm{a}}$ & Data source \\
\hline $\begin{array}{l}T_{\text {surf }} \\
\text { WSP }_{\text {surf }} \\
\text { RH } \\
\text { SRAD }\end{array}$ & $\begin{array}{l}\text { Daytime mean }{ }^{\mathrm{b}} \text { surface temperature } \\
\text { Daytime mean wind speed } \\
\text { Daytime mean relative humidity } \\
\text { Daytime mean solar radiation }\end{array}$ & $\begin{array}{l}\text { CASTNet surface monitoring sites in the } \\
\text { US Intermountain West (http://www.epa.gov/castnet), } \\
\text { for } 13 \text { CASTNet sites only }\end{array}$ \\
\hline $\begin{array}{l}\text { Tmax } \\
\text { AWND }\end{array}$ & $\begin{array}{l}\text { Daily maximum temperature } \\
\text { Daily average daily wind speed }\end{array}$ & $\begin{array}{l}\text { NOAA, National Climatic Data Center: } \\
\text { Climate Data Online } \\
\text { (http://www.ncdc.noaa.gov/cdo-web/), } \\
\text { for Salt Lake City urban site only }\end{array}$ \\
\hline PBLH & Gridded daily maximum planetary boundary height & $\begin{array}{l}\text { NCEP Climate Forecast System Reanalysis (http://rda } \\
\text { ucar.edu/datasets/ds093.0/) }\end{array}$ \\
\hline$U$ & Gridded daily mean $850,700,500 \mathrm{hPa}$ zonal wind & NCEP/NCAR Reanalysis dataset \\
\hline$V$ & Gridded daily mean $850,700,500 \mathrm{hPa}$ meridional wind & (http://www.esrl.noaa.gov/psd/data/timeseries/daily/) \\
\hline WSP & Gridded daily mean $850,700,500 \mathrm{hPa}$ horizontal wind & \\
\hline Ome & Gridded daily mean $850,700,500 \mathrm{hPa}$ vertical velocity & \\
\hline $\mathrm{SH}$ & Gridded daily mean $850,700,500 \mathrm{hPa}$ specific humidity & \\
\hline HGT & Gridded daily mean $850,700,500 \mathrm{hPa}$ geopotential heights & \\
\hline$T$ & Gridded daily mean $850,700,500 \mathrm{hPa}$ temperature & \\
\hline $\mathrm{d} T$ & Gridded daily mean temperature at $1000 \mathrm{mb}$ minus that at $850 \mathrm{hPa}$ & \\
\hline
\end{tabular}

For each day at a receptor site, FLEXPART was run in backward mode, with 250000 particles released at the site location at a constant hourly rate $(\sim 10 \mathrm{k}$ particles per hour $)$ during the first $24 \mathrm{~h}$. Previous studies have used the particle sizes of 40000 (Cooper et al., 2010) and 1 million (Stohl et al., 2012) represent a retroplume. Each particle carries a small amount of mass decaying with an e-folding time of 5 days (mean lifetime of ozone in the Intermountain West due to chemical loss and dry deposition as shown in Fiore et al., 2002). Trajectories of these particles are calculated backwards for 5 days $(120 \mathrm{~h})$, together tracing the retroplume of the air arriving at the site. The model outputs are in the same $0.5^{\circ} \times 0.5^{\circ}$ horizontal resolution as the wildfire burned area data and are hourly residence times of the particles in each grid cell. The residence time provides a quantitative measure of the sensitivity of the simulated mixing ratio at the site location to emission input (Stohl et al., 2003; Seibert and Frank, 2004; Cooper et al., 2010). In total, we have computed over 28000 FLEXPART retroplumes for the 13 Intermountain West CASTNet sites and SLC site for the summers 1989-2010.
We then define an FI as the product of daily FLEXPART residence time integrated from the surface to $5 \mathrm{~km}$ and daily wildfire burned area, in unit of $\mathrm{s} \times$ ha. We use $5 \mathrm{~km}$ in the vertical because previous studies have shown that fire emissions are occasionally lifted to above the planetary boundary layer up to $5 \mathrm{~km}$ above the surface (Val Martin et al., 2010; Sofiev et al., 2013), and, as shown in Table S1 in the Supplement, it provides slightly better correlations with the OC aerosol concentrations than values with $2 \mathrm{~km}$ and 2-4 days. The sum of FI over the 5-day period is defined as total fire index (TFI). The formulas are given as

$$
\begin{aligned}
& \mathrm{FI}(n)={ }^{\circ} \sum_{i} \sum_{j} \mathrm{E}_{\mathrm{fire}(i, j, n)} \times \mathrm{t}_{r(i, j, n)} \\
& \mathrm{TFI}={ }^{\circ} \sum_{n=1}^{5} \mathrm{FI}(n) .
\end{aligned}
$$

Here $\mathrm{E}_{\mathrm{fire}(i, j, n)}$ is the wildfire burned area in the model grid cell $i$ (longitude) and $j$ (latitude) on day $n, \mathrm{t}_{r(i, j)}$ is FLEXPART calculated daily residence time as described in detail by Stohl et al. (2003) and Seibert and Frank (2004), and $n$ defines the backward day in the 5-day period. Figure S1 in the Supplement shows an example of FI for the site CAN on 14 July 2006. In this case, the particles are released on 14 July (day $n=1$ ) in the FLEXPART model, and daily res- 
idence time is calculated backwards for 5 days (10-14 July). $\mathrm{FI}(5)$ then represents the product of residence time on 10 July and wildfire areas burned on that day. TFI as the sum of FI(1)-FI(5) estimates the total impact of wildfires during the 5 days for that site and day.

\subsection{Multiple linear regression model}

We build MLR models of summer ozone concentrations for the 13 CASTNet sites and SLC site using FI and meteorological parameters as predictors. This method has been previously used to identify the meteorological factors determining concentrations of particulate matter or ozone (Camalier et al, 2007; Tai et al., 2010, 2012; Jaffe et al., 2013). Here we use the metric of daily maximum 8-hour average (MDA8) ozone concentration, as it is the regulatory form of the NAAQS. A total of 28 meteorological parameters are considered in the MLR models including those measured at surface and from NCEP data (Tables 1 and 2). Some of these meteorological variables, such as surface temperature, relative humidity, and upper level winds, have been shown before to be correlated with surface ozone in the western US (Jacob et al., 2009; Rasmussen et al., 2012; Jaffe et al., 2013).

Wildfire ozone enhancements are sensitive to plume ages. As summarized in Jaffe et al. (2012), $\Delta \mathrm{O}_{3} / \Delta \mathrm{CO}$ values in wildfire plumes show distinct differences for plume ages of $1-2$ days (average 0.018 ppbv ppbv $^{-1}$ ) vs. $3-5$ days (average $\left.0.15 \mathrm{ppbvpbv}^{-1}\right)$. Thus instead of using TFI, we separate it to $\mathrm{FI}_{\mathrm{s}}(\mathrm{FI}(1)+\mathrm{FI}(2))$ and $\mathrm{FI}_{1}(\mathrm{FI}(3)+\mathrm{FI}(4)+\mathrm{FI}(5))$ in the MLR models. We also include the square root of $\mathrm{FI}_{\mathrm{S}}$ and $\mathrm{FI}_{1}$ $\left(\mathrm{SqrFI}_{\mathrm{S}}\right.$ and $\left.\mathrm{SqrFI}_{1}\right)$ as variables in the regression model to at least partly account for the nonlinearity of ozone chemistry in wildfire plumes and to narrow the distribution of FI values that are highly episodic. We do not use the natural logarithm form of FI in MLR, because many of the FI values are zero, which would cause invalid values in the regression.

The MLR models can be described as

$$
\begin{aligned}
y & =\alpha_{1} \times \mathrm{FI}_{\mathrm{s}}+\alpha_{2} \times \mathrm{FI}_{1}+\beta_{1} \times \mathrm{SqrFI}_{\mathrm{s}}+\beta_{2} \times \mathrm{SqrFI}_{1} \\
& +\sum_{p=1}^{m} \gamma_{p} \times \operatorname{met}_{p}+c .
\end{aligned}
$$

Here $y$ is MDA8 ozone concentration, $\alpha \beta \gamma$ are the regression coefficients, met denotes the $m$ meteorological parameters included, and $c$ is the constant term. We then estimate ozone enhancements from wildfires and we refer it as MLR wildfire ozone, following

$$
y_{\text {fire }}=\alpha_{1} \times \mathrm{FI}_{\mathrm{s}}+\alpha_{2} \times \mathrm{FI}_{1}+\beta_{1} \times \mathrm{SqrFI}_{\mathrm{s}}+\beta_{2} \times \mathrm{SqrFI}_{1} \text {. }
$$

The remaining components define the contribution from other variables such as meteorology and other sources:

$y_{\text {nofire }}=\sum_{p=1}^{m} \gamma_{p} \times \operatorname{met}_{p}+c$.
To further account for the nonlinear ozone response to wildfire emissions, we divide the ozone records for each site into three subsets based on their TFI values: subsets with TFI $=0$, with the lower $50 \%$, and with upper $50 \%$ TFI values (with $\mathrm{TFI}=0$ excluded). In this way we are able to quantify potentially different ozone drivers under high vs. low wildfire conditions. The MLR models as described above are applied to each subset.

Prior to performing the regression, we calculate correlations among ozone and all predictors and remove those factors that show weak correlation with ozone but strong dependence on other predictors. To minimize the collinearity in the MLR model, we also apply the stepwise regression method; i.e., for each step the model selects the most powerful and significant $(p<0.05)$ predictor explaining the residual and removes predictors with insignificant influence $(p>0.1)$ (Field et al., 2009). We do not include the interaction terms to simplify the MLR models. We acknowledge that including FI and meteorological parameters while neglecting their interaction terms in the MLR models inevitably leads to some degree of collinearity. A measure of it is called tolerance (calculated as percent of variance in the predictor that cannot be accounted for by the other predictors) or variance inflation factors (VIF; the inverse of tolerance), with VIF values greater than 10 suggesting a strong collinearity (Field et al., 2009). Our MLR models for all sites (Sect. 3) show tolerable VIF values $(<5)$, supporting our approach described above to limit the collinearity.

\subsection{The GEOS-Chem model simulations}

We further conduct GEOS-Chem model simulations to estimate wildfire ozone enhancements and to compare with those from the Lagrangian and statistical approach as described above. The GEOS-Chem chemical transport model is driven by the GEOS-5 assimilated meteorological fields from the NASA Global Modeling and Assimilation Office (GMAO) (http://www.geos-chem.org; v8-02-03) (Bey et al., 2001). We use a nested version of GEOS-Chem that has $1 / 2^{\circ} \times 2 / 3^{\circ}$ horizontal resolution over North America and adjacent oceans $\left(140-40^{\circ} \mathrm{W}, 10-70^{\circ} \mathrm{N}\right)$ and $2^{\circ} \times 2.5^{\circ}$ over the rest of the world. We conduct the GEOS-Chem ozone simulations over North America for 3 years (2006-2008) using the wildfire burned area of Yue et al. (2013). Zhang et al. (2014) have suggested that wildfire $\mathrm{NO}_{x}$ emission factor in the standard GEOS-Chem simulation can be too high by a factor of 3 . We thus also conduct a sensitivity simulation with a reduced wildfire $\mathrm{NO}_{x}$ emission factor (from 3.0 to $1.0 \mathrm{~g}$ NO per $\mathrm{kg}$ of dry mass burned following Zhang et al., 2014). Wildfire ozone enhancements are computed as differences between the simulation with all emissions turned on and a sensitivity simulation with only wildfire emissions turned off. 
Table 2. Multiple linear regression (MLR) models for summer MDA8 ozone at 13 Intermountain West CASTNet sites ${ }^{\mathrm{a}}$.

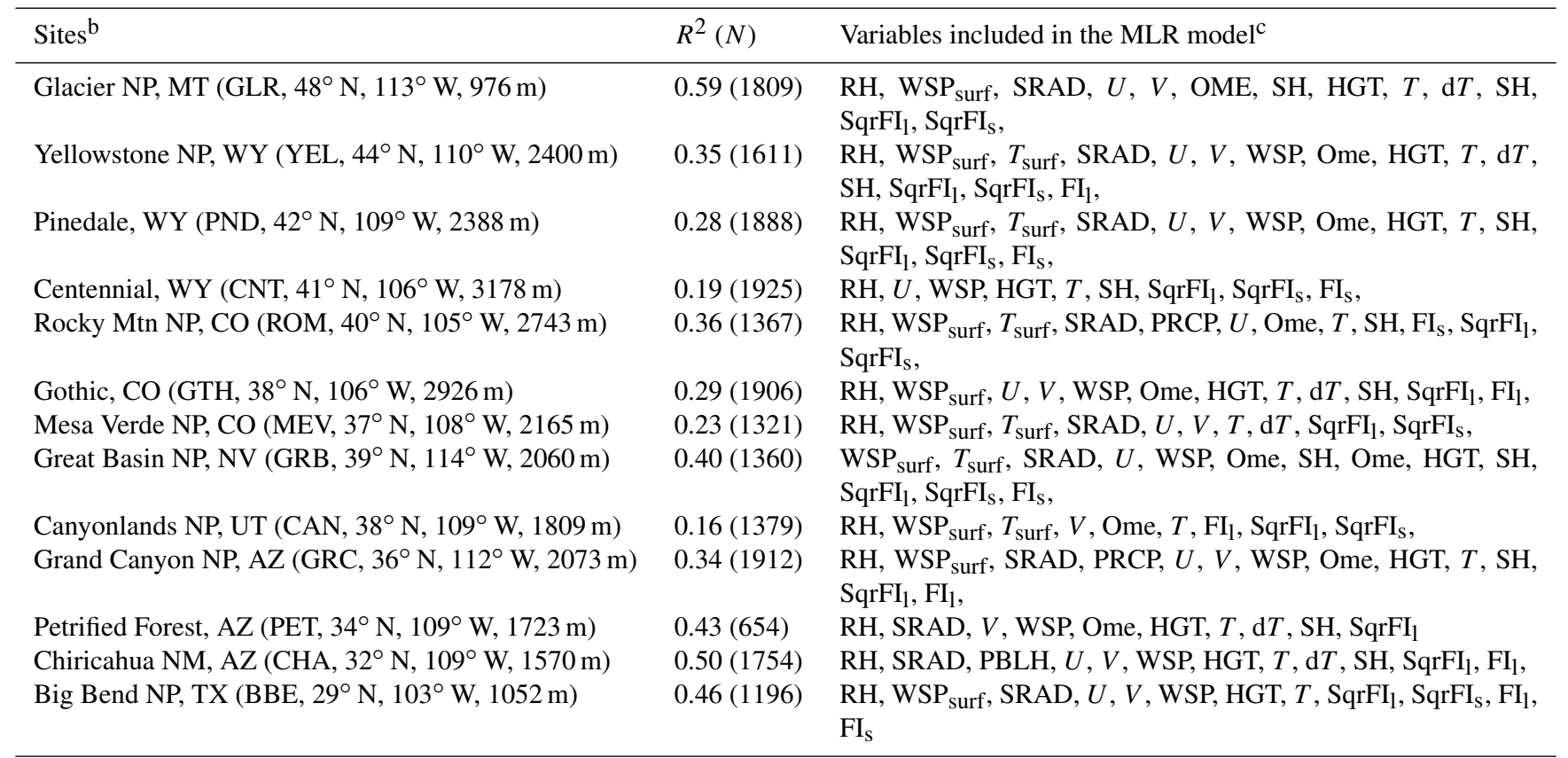

a Coefficients of determination $\left(R^{2}\right)$, sample numbers $(N)$, and variables included in the MLR models. ${ }^{\mathrm{b}}$ NP is National Park, NM is National Monument, MT is Montana, WY is

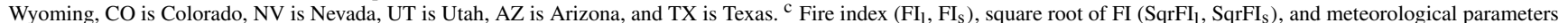
including (1) surface measurements: daytime (10:00-17:00 LT) mean temperature ( $T_{\text {surf }}$ ), wind speed (WSP surf ), relative humidity (RH), and solar radiation flux (SRAD); (2) gridded daily precipitation (PRCP); (3) NCEP data at $850 / 700 / 500 \mathrm{hPa}$ pressure levels: daily maximum planetary boundary layer height (PBLH), daily mean zonal wind speed $(U)$, meridional wind speed $(V)$, horizontal wind speed (WSP), temperature $(T)$, geopotential height (HGT), vertical velocity (Ome), specific humidity (SH), and temperature at $1000 \mathrm{hPa}$ minus that at $850 \mathrm{hPa}(\mathrm{d} T)$. Please refer to Tables 1 and S2 for details on the parameters and MLR models.

\section{Model evaluation}

We first evaluate our Lagrangian-based FI using its correlation to OC aerosol concentrations, as previous studies have shown that wildfires are an important source of OC aerosols in the US Intermountain West in summer (Park et al., 2007; Spraklen et al., 2007). As shown in Fig. S2 and Table S1, the TFI values at each CASTNet site are positively correlated with OC aerosol concentrations measured at collocated IMPROVE sites ( $r=0.19-0.44)$. While the TFI vs. OC correlations are not very strong, reflecting both uncertainties in the FLEXPART retroplumes and influence from other OC aerosol sources, the correlations are better $(p<0.01)$ than those with areas burned within $10^{\circ} \times 10^{\circ}$ regions. We also test the correlations of OC aerosols with FI calculated using trajectory residence time at lower altitudes or shorter backward time periods, and they in general show slightly weaker correlations (Table S1).

Table 2 summarizes the predictors included in the MLR models and their performance for each CASTNet site with more details given in Table S2. The MLR models explain 16$59 \%$ of the variability in MDA8 ozone concentration among these sites. Figure 2 shows the comparison of measured and MLR predicted ozone concentrations for the ensemble of 13 CASTNet sites. The MLR models generally reproduce the ozone measurements $\left(R^{2}=0.60\right)$. These coefficients of de- termination $\left(R^{2}\right)$ are comparable with, or even better than, results simulated by Eulerian CTMs (e.g., $R^{2}=0.43$ in Zhang et al., 2014; $R^{2}=0.25$ in Emery et al., $2012 ; R^{2}=0.48$ in Strode et al., 2015) that have limited ability to reproduce the measured ozone variability in the Intermountain West probably due to the coarse model resolution and complex topography. However, they are lower than results from Jaffe et al. (2013) or Camalier et al. (2007) that applied the regression models on ozone concentrations at US urban and lowaltitude sites.

Jaffe et al. (2013) analyzed the surface ozone concentrations measured at the SLC urban site in the western US during June-September 2000-2012 and showed that a MLR model using meteorological variables as predictors could explain $60 \%$ of the MDA8 ozone variation. Here we also applied our MLR models to MDA8 ozone concentrations at SLC in the summers 1990-2010. We find FI and meteorological variables can explain $48 \%$ of the daily MDA8 ozone variation for summers 1990-2010 (46\% if meteorological variables alone are used and $57 \%$ if September data are also considered, which explains the higher correlation reported in Jaffe et al., 2013), which is a higher value than at most of the CASTNet sites. In addition, as shown in Table 2 and Fig. S3 the MLR model $R^{2}$ values for higher-altitude CASTNet sites ( $>2000 \mathrm{~m}$ such as CNT, MEV, PND) are generally lower than values for lower-altitude sites (such as GLR, CHA, and 


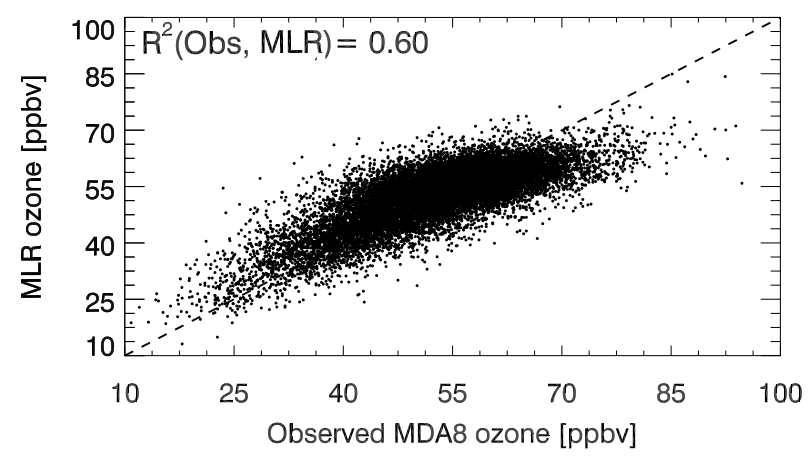

Figure 2. Comparison of the measured versus MLR predicted MDA8 ozone concentrations in the summers 1989-2010 for the ensemble of 13 Intermountain West CASTNet sites. The $1: 1$ line (dashed line) and the squared correlation are shown in the inset.

BBE). It appears that the MLR model performs better for US urban and low-altitude sites than for the CASTNet highaltitude background sites. This is likely because ozone at the high-altitude CASTNet sites is more affected by regional transport from both anthropogenic and natural sources, such as lightning and stratospheric ozone, and less controlled by local meteorology relative to ozone at urban or low-altitude sites.

We find that at the CASTNet sites daytime mean $\mathrm{RH}$ is generally the most important predictor. In the low- $\mathrm{NO}_{x}$ background environment, $\mathrm{HO}_{x}$ serves as a strong sink for ozone driving the correlation with water vapor concentrations (hence RH) (Doherty et al. 2013; Pusede et al., 2015). Fire impacts $\left(\mathrm{FI}_{\mathrm{s}}\right.$ and $\left.\mathrm{FI}_{1}\right)$ are included for different sites, as would be expected by their different travel times from the frequent burning areas to the receptor sites. SqrFI often shows a higher explanatory power than FI, reflecting nonlinear ozone production from wildfire emissions.

We also acknowledge that the MLR models underestimate high ozone values especially when measured MDA8 ozone exceeds 70 ppbv (Fig. 2). These underestimates, however, are not likely due to model underestimates of wildfire ozone influences. We show in Fig. 3 the relationships of TFI values with measured MDA8 ozone, MLR wildfire ozone enhancements, and MLR residuals to assess the model performance for the subset of high ozone days (MDA8 $>70 \mathrm{ppbv}$ ). The MLR model residuals for those high ozone days have little correlation with TFI, and most of the model underestimates occur when there are small fire impacts or fires not captured by the FLEXPART retroplumes. We suggest these underestimates may be associated with other factors not included in the statistical model such as transport from Asia or California, from lightning emissions or stratosphere. These processes could episodically produce more than $10 \mathrm{ppbv}$ ozone in summer over the US Intermountain West (Zhang et al., 2014).
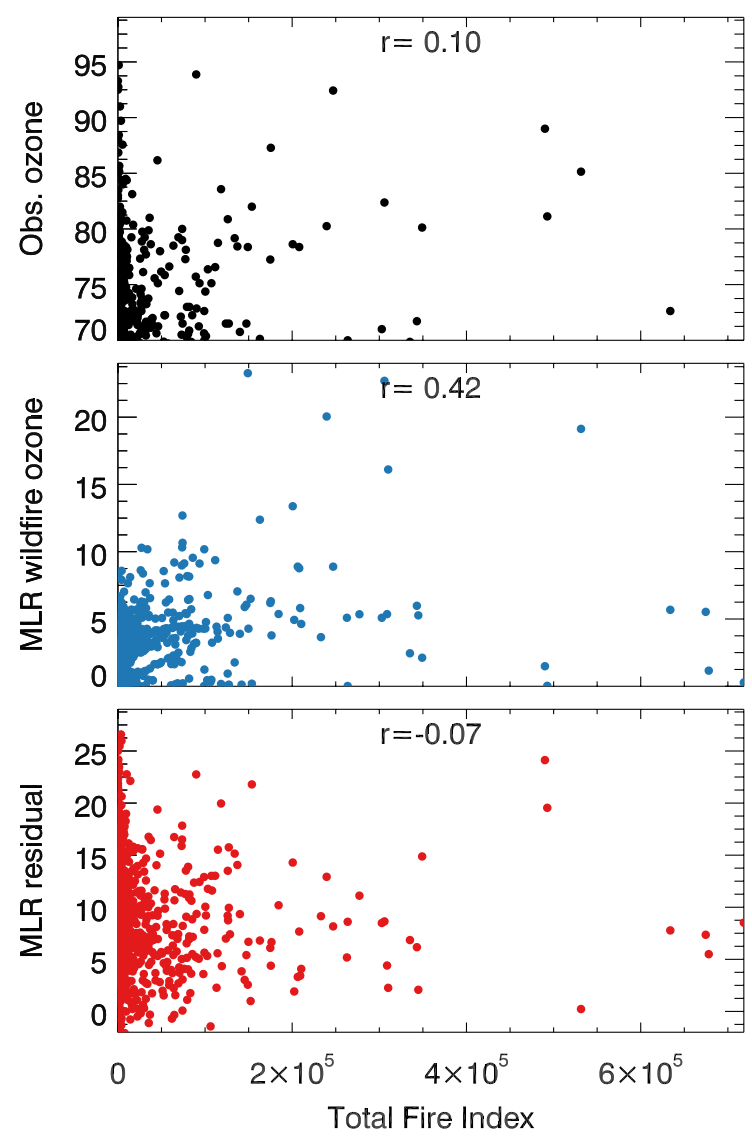

Figure 3. Evaluation of the MLR model low biases (MLR residuals) when measured MDA8 ozone concentration exceeds $70 \mathrm{ppbv}$ as indicated in Fig. 2. Scatter plots of total fire index (TFI) versus measured MDA8 ozone (top panel), MLR wildfire ozone enhancements (middle panel), and MLR residuals (bottom panel) are shown. The correlation coefficients are also shown inset.

\section{Results}

\subsection{Consistency and difference with the Eulerian model}

It is of particular value to evaluate the MLR wildfire ozone enhancements with those from the Eulerian approach. We show in Fig. 4 such a comparison with the wildfire ozone enhancements estimated by the GEOS-Chem model in the summer 2007 when there are large wildfire emissions in Idaho. We can see that the GEOS-Chem model simulates a sharp gradient of wildfire influences with ozone enhancements greater than 20 ppbv over the Idaho and Montana burning areas, which decrease rapidly downwind to $0.5-3 \mathrm{ppbv}$.

To evaluate the MLR wildfire ozone enhancements, we separate the 13 CASTNet sites into three groups based on their distances to the major burning area in Idaho. As shown in Fig. 4, the MLR and GEOS-Chem estimated wildfire ozone enhancements for all three groups are moderately correlated ( $r=0.34-0.48$, statistically significant $p<0.05)$, reflecting some consistency between the two approaches. 

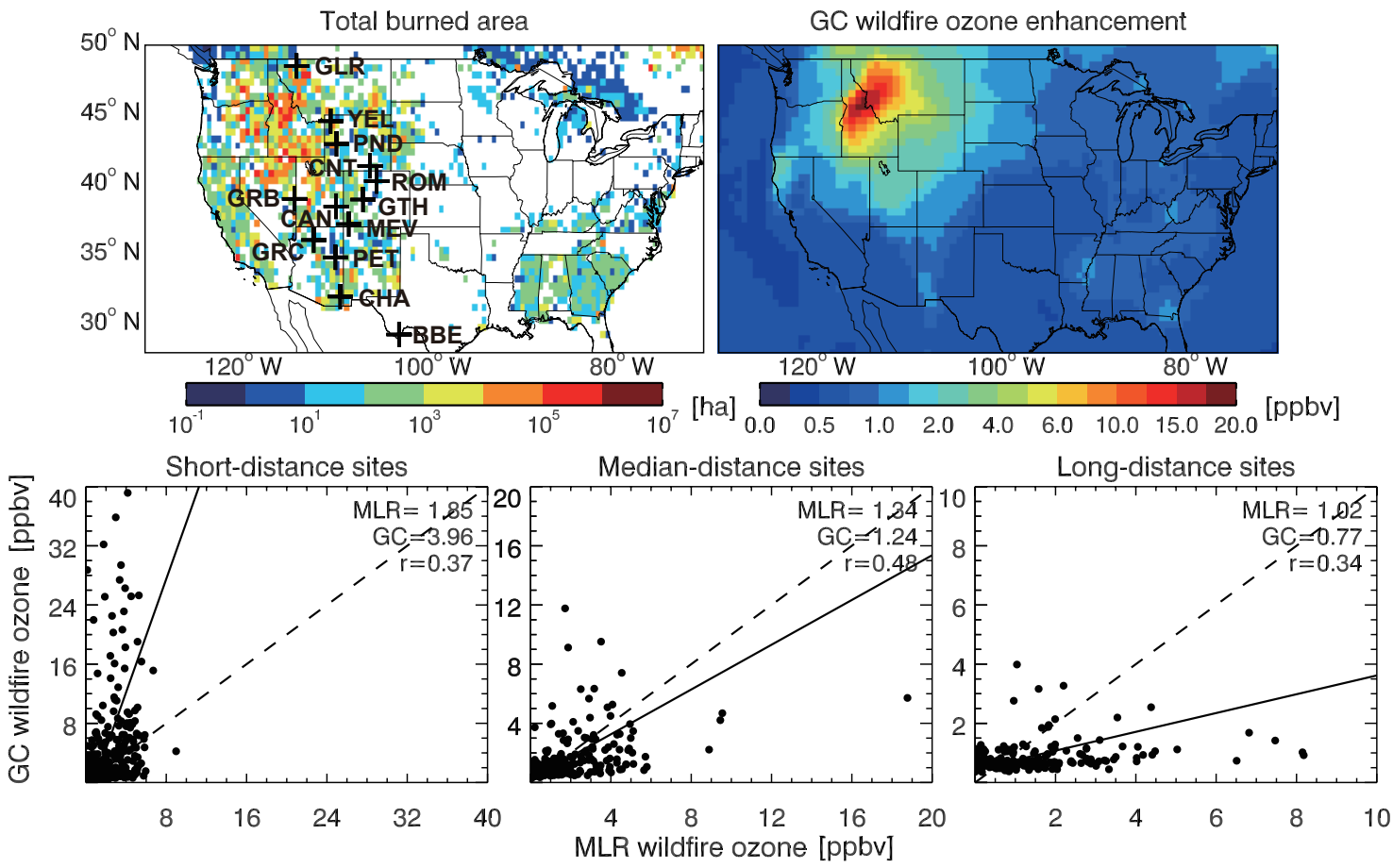

Figure 4. Wildfire ozone enhancements over the Intermountain West US in summer 2007. Top panels show the total burned area (upperleft panel) and seasonal mean wildfire ozone enhancements computed by the GEOS-Chem simulation (upper-right panel). Wildfire ozone enhancements computed by the MLR models are compared with those from the GEOS-Chem simulation. The comparisons are separated by their distances to the location with the maximum fire emission in Idaho: short-distance sites (bottom-left; GLR, YEL, PND, and GRB), median-distance sites (bottom-middle; CNT, ROM, GTH, CAN, MEV, and GRC), and long-distance sites (bottom-right; PET, CHA, and $\mathrm{BBE}$ ). Mean wildfire ozone enhancements, correlation coefficients $(r)$, reduced-major-axis regression lines (solid), and $1: 1$ lines (dashed) are shown inset.

There are also considerable differences. We can see that GEOS-Chem simulates up to $40 \mathrm{ppbv}$ wildfire ozone enhancements for the short-distance sites, much higher than the MLR estimates (mean value of $3.96 \mathrm{ppbv}$ vs. $1.85 \mathrm{ppbv}$ ). A sensitivity simulation with a reduced wildfire $\mathrm{NO}_{x}$ emission factor (from 3.0 to $1.0 \mathrm{~g}$ NO per kg of dry mass burned) would decrease the GEOS-Chem mean ozone enhancement for the short-distance sites from 3.96 to $2.06 \mathrm{ppbv}$. In contrast, for the long-distance sites, the GEOS-Chem wildfire ozone enhancements become substantially lower than MLR ( 0.77 ppbv vs. $1.02 \mathrm{ppbv}$ ). We see GEOS-Chem largely overestimates wildfire ozone influences near the source regions but fails to capture continued ozone production in wildfire plumes downwind, as also pointed out by Zhang et al. (2014). It reflects the difficulties for Eulerian models such as GEOSChem to simulate wildfire ozone production due to, for example, missing short-lived VOCs (Jaffe and Wigder, 2012), inadequate PAN chemistry (Alvarado et al., 2010; Fischer et al., 2014), and limiting all fire emissions in the boundary layer without considering their injection heights up to the troposphere (Val Martin et al., 2010; Sofiev et al., 2013). The lower GEOS-Chem wildfire ozone estimates at those longdistance sites may be also attributed to the model difficulty in simulating ozone production from small-scale fires nearby. The MLR approach appears to show a more reasonable pattern.

\subsection{Contribution of wildfires to the MDA8 ozone concentration}

We use the MLR models to diagnose the influences of wildfires and other meteorological parameters on MDA8 ozone concentrations at the Intermountain West CASTNet sites. Figure 5 shows the scatter plots of observed MDA8 ozone and MLR predicted ozone at four selected sites located in different regions (GLR, ROM, GRB, and CHA). Also shown are the box plots of MLR wildfire ozone enhancements and MLR no wildfire ozone as defined by Eqs. (4) and (5), respectively. The MLR models generally reproduce the measurements except for high ozone values as we have discussed above. For all the CASTNet sites, the MLR no wildfire ozone explains most of the measured MDA8 variability $\left(R^{2}=0.10-0.58\right)$ compared to MLR wildfire ozone enhancements $\left(R^{2}=0.02-0.12\right)$. However, wildfire ozone enhancements increase as measured MDA8 ozone concentrations increase, reflecting higher wildfire impacts on the highozone events. We can see in a few cases wildfire ozone 


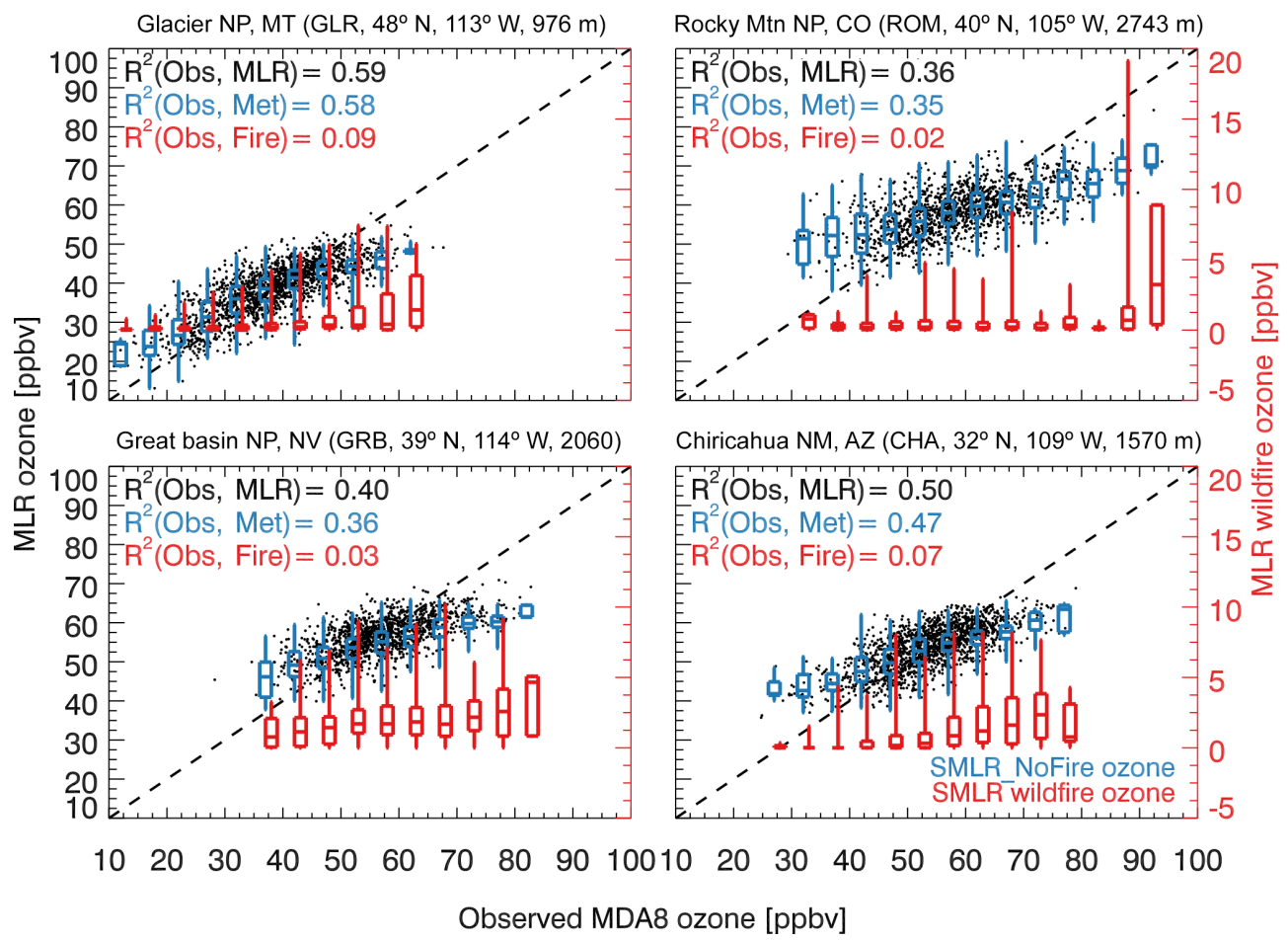

Figure 5. Scatter plots of observed versus MLR predicted MDA8 ozone concentrations at 4 selected CASTNet sites for the summers 19892010. Also shown are the box-and-whisker plots (minimum, 25th, 50th, and 75th percentiles, and maximum) of ozone without wildfire influences (blue) and wildfire ozone enhancements (red) for 5 ppbv bins of observed ozone concentrations; both are computed by the MLR model as described in the text. The $1: 1$ line (dashed line) and the coefficient of determination $\left(R^{2}\right)$ are shown inset.

enhancements reach 10-20 ppbv, causing measured MDA8 ozone to approach the ozone quality standard of $70 \mathrm{ppbv}$.

Another test to separate wildfire ozone influences from meteorological impacts follows Jaffe et al. (2008), who showed ozone concentrations in high fire years were distinctly greater than those in low fire years at the same temperature ranges. Here we extend their approach to other meteorological parameters and to the whole 22-year records. Figure 6 shows the relationships between MDA8 ozone concentrations and meteorological parameters (daytime temperature, wind speed, $\mathrm{RH}$, and solar radiation flux) measured at a Chiricahua National Monument, Arizona (CHA). We compare measured MDA8 ozone concentrations with high versus low wildfire impacts (upper $33 \%$ versus lower $33 \%$ of the TFI values). Meteorological variations have some impacts on both wildfire activities and MDA8 ozone levels. High wildfire events are prone to occur with high temperature and solar radiation and low $\mathrm{RH}$ and wind speed, as indicated by the number of upper $33 \%$ vs. lower $33 \%$ TFI occurrences in each increment of meteorological parameters. Ozone concentrations generally increase with increasing temperature and decreasing RH. We can also see significant differences $(p<0.05)$ in the MDA8 ozone concentrations between the upper and lower TFI values for most of the meteorological increments. For instance, in the $26-28^{\circ} \mathrm{C}$ temperature bin, the mean MDA8 ozone for the upper $33 \%$ TFI is about $8 \mathrm{ppbv}$ higher than that for the lower $33 \%$ TFI. This confirms impacts of wildfires on ozone that are independent from meteorological variables.

\subsection{Wildfire influences on the ozone interannual variability and trend}

Application of the MLR models to the summers 1989-2010 ozone measurements allows us to quantify wildfire influences on the long-term ozone variability and trend. We show in Fig. 7 time series of summer mean measured and MLR predicted MDA8 ozone concentration for the Intermountain West regional average, as well as for three individual sites (GLR, YEL, and GRC) in the 22 years (1989-2010). The MLR models show good agreements with measurements with correlation coefficients of 0.85 for the regional average and $0.52-0.92$ for individual sites, but they underestimate the measured interannual variability. Figure 7 also shows the summer mean MLR with and without the wildfire ozone, along with the difference between the two. The interannual variability of surface ozone over the region appears to be more controlled by the interannual variations of meteorological parameters, and hence the climate variability, as we can see that even without wildfire influences, the remaining meteorological parameters used in the MLR models still predict most of the interannual variability (MLR no wildfire ozone 

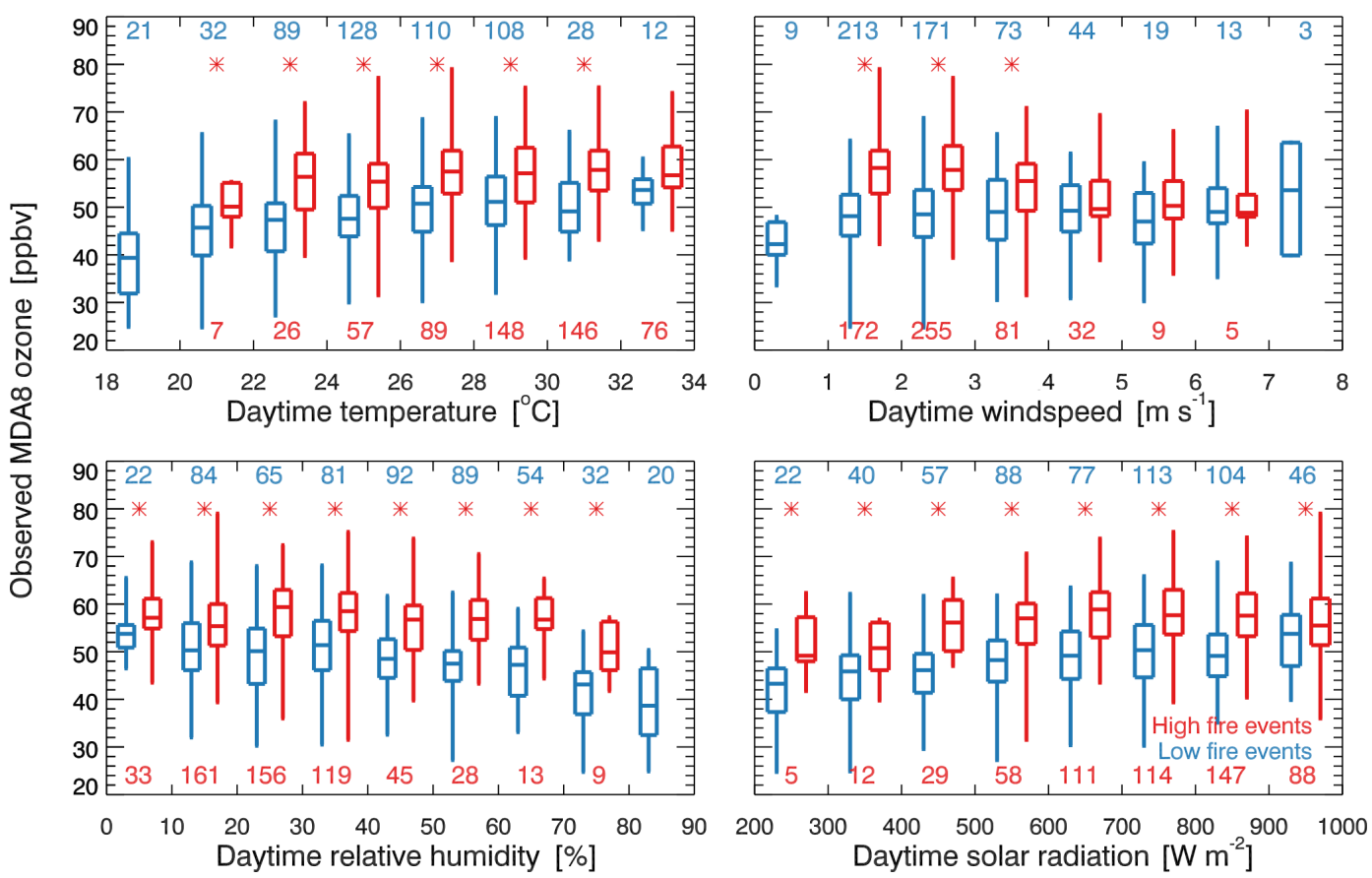

Figure 6. Box-and-whisker plots (minimum, 25th, 50th, and 75th percentiles, and maximum) of observed MDA8 ozone concentrations for bins of observed daytime meteorological parameters at CHA site: temperature (upper-left), wind speed (upper-right), relative humidity (bottom-left), and solar radiation flux (bottom-right). MDA8 ozone concentrations are divided by high (TFI at top 33\%, red) and low (TFI at lower $33 \%$, blue) fire events with the number of occurrences in each bin shown inset. Significant difference $(p<0.05)$ is marked by asterisks.

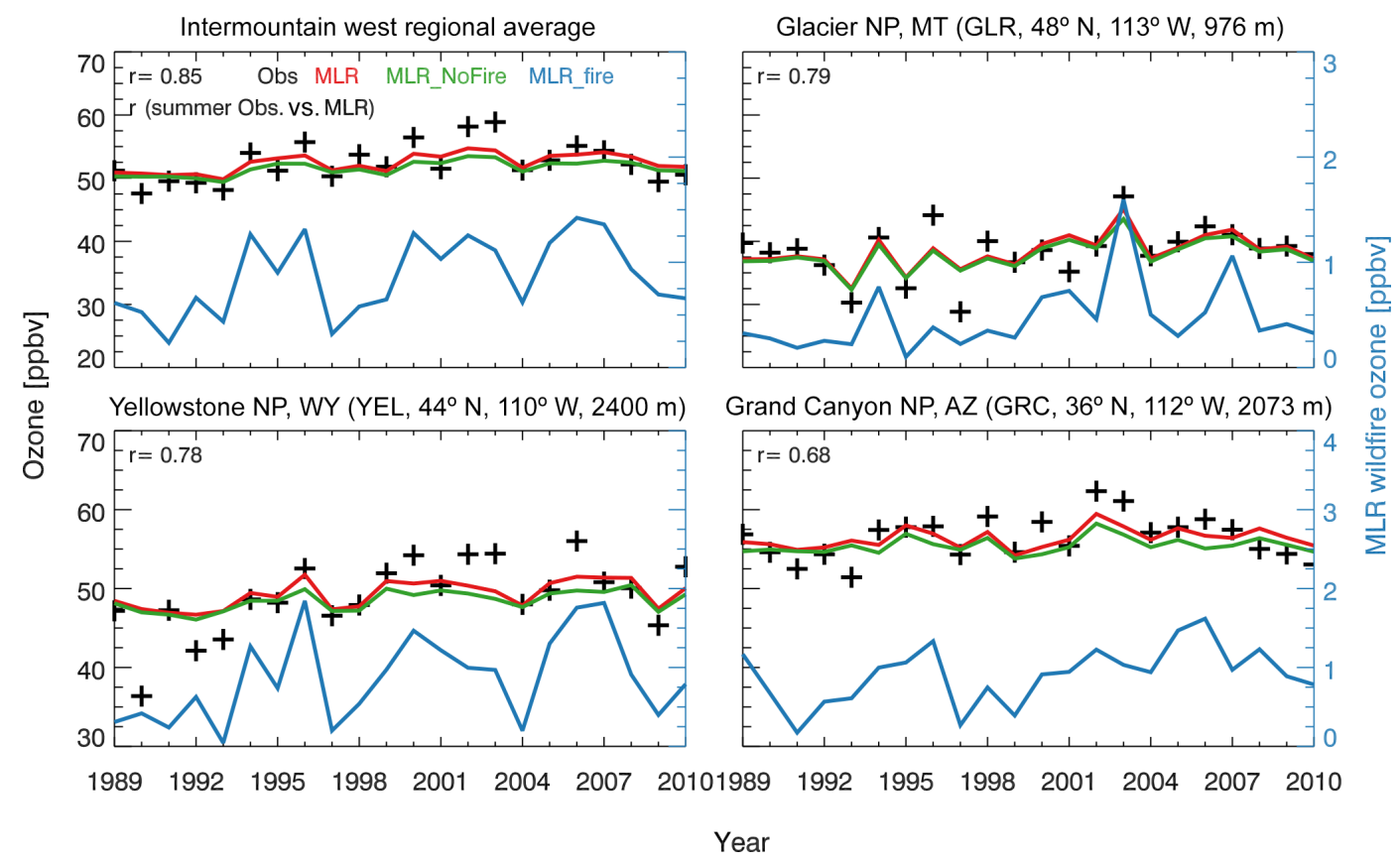

Figure 7. Time series of summer mean MDA8 ozone concentrations for the regional averages of eight CASTNet sites with complete 22-year measurements as well as three individual sites. Measurements (black pluses) are compared to the MLR model results (red line). Also shown are the summer mean MLR no wildfire ozone (green line) and MLR wildfire ozone (blue line, right axis). The correlations between measured and MLR summer means are shown inset. 
vs. MLR ozone $r=0.87-0.99$ among individual sites). This is further supported by the strong interannual correlations between summer mean MDA8 ozone and meteorological parameters such as daytime mean $\mathrm{RH}$ and surface temperature at individual sites and for the regional averages $(r=-0.69$ for $\mathrm{RH}, r=0.48$ for temperature), as shown in Fig. S4.

Wildfires contribute $0.3-1.5$ ppbv to the summer mean surface MDA8 ozone averaged over the Intermountain West CASTNet sites. In the high fire activity years such as 2003 and 2007, the summer mean wildfire ozone enhancements can reach $3.5 \mathrm{ppbv}$ at the individual sites, e.g., MEV. The interannual variability of wildfire ozone enhancements is strongly correlated with that of the MLR total ozone ( $r=$ 0.89 for the regional averages and $0.48-0.87$ for individual sites). As we can see here, the wildfire-driven interannual variability $(0.3-1.5 \mathrm{ppbv})$ is much weaker than what can be explained by meteorological parameters (49.4-53.5 ppbv for the regional averaged MLR no wildfire ozone). We suggest that some of the strong correlation between summer mean surface ozone concentrations and wildfire activities reflects their common relationships with meteorological parameters such as RH and temperature at the interannual scale; e.g., hot and dry summers would have higher ozone concentrations due to stronger photochemistry as well as more wildfire emissions than cold and wet summers (Fig. S4). However, we should acknowledge that ozone production in wildfires varies significantly (Jaffe and Wigder, 2012), and the statistical models we use here can still underestimate the interannual variations of wildfire influences. Better resolving the causes of variations in wildfire ozone production will help us understand the source for interannual variations in ozone.

We further calculate the linear trends of surface ozone in the summers 1989-2010. Figure 8 summarizes the results at three percentile ranges: $93-97$ th, $48-52$ th, 3-7th percentiles at the Intermountain West CASTNet sites. The three percentile ranges are used to quantify trends in the low, median, and high windows of summer MDA8 ozone concentration. They also allow us to properly calculate the corresponding mean wildfire ozone contributions to total ozone by using percentile ranges rather than a single percentile. We find similar results when using other percentile ranges (49-51th or 47-53th). We also show the separated trends for the earlier (1989-1999) and later (2000-2010) periods following Strode et al. (2015), who suggested different trends in surface ozone for the two periods. Regional averaged summer MDA8 ozone concentrations in the Intermountain West show increasing but statistically insignificant trends of $0.14 \pm 0.21(p=0.22), 0.19 \pm 0.21$ $(p=0.08)$, and $0.18 \pm 0.20 \quad(p=0.09) \mathrm{ppbv} \mathrm{yr}^{-1}$ at the 93-97th, 48-52th, and 3-7th percentiles, respectively, in 1989-2010. Statistically significant $(p<0.05)$ increasing trends are found at the YEL $\left(0.42 \pm 0.30 \mathrm{ppbv} \mathrm{yr}^{-1}\right)$ and $\operatorname{ROM}\left(0.43 \pm 0.39 \mathrm{ppbv} \mathrm{yr}^{-1}\right)$ sites at the median percentiles. These increasing trends primarily occurred in the earlier period (1989-1999), while nearly all sites show decreasing ozone trends during 2000-2010. Strode et al. (2015) attributed the earlier increasing trends to meteorological variations and the later decreasing trends to domestic emission controls. Our results are consistent with previous studies of Cooper et al. (2012) and Strode et al. (2015), who analyzed the ozone trends using the same CASTNet measurements but using the metric of daytime ozone concentration.

Also shown in Fig. 8 are the corresponding ozone trends contributed by wildfires as estimated by the MLR models. A distinct feature is that the trends of wildfire ozone enhancements are relatively small but generally in the same directions as the observed ozone trends. This feature can also result from meteorological variations that modulate surface ozone concentrations and wildfires in similar directions. Most of the sites show increasing wildfire ozone in the first 11 years (1989-1999) and switch to decreases in the next 11 years (2000-2010), but only a few of them are statistically significant. Wildfire ozone enhancements averaged over the Intermountain West CASTNet sites increase at rates of $0.02 \pm 0.05(p=0.48), 0.02 \pm 0.05(p=0.38)$, and $0.03 \pm 0.03 \mathrm{ppbv} \mathrm{yr}^{-1}(p<0.05)$ at the 93-97th, 48-52th, and $3-7$ th percentile ranges, respectively, in the summers 1989-2010. These values account for about $15 \%$ of the observed ozone trends at the same CASTNet sites, representing small but important ozone influences from wildfires.

\subsection{Wildfire influences on ozone exceedance days}

As the ozone air quality standard becomes stricter, it is important to quantify the number of ozone exceedances caused partly by uncontrollable sources, such as wildfires. We show in Fig. 9 the mean number of days with measured MDA8 ozone concentrations exceeding 75, 70, and 65 ppbv averaged over the 13 Intermountain West CASTNet sites in the summers 1989-2010. Also shown is the corresponding number of exceedances that would be present in the absence of wildfires (estimated as measured ozone minus the MLR wildfire ozone). We find no statistically significant trends in the number of exceedances for both the measured ozone concentrations and ozone in the absence of wildfires during the summers 1989-2010.

In the years with poor air quality conditions such as 2002 and 2003, there were more than 20 days when MDA8 ozone exceeds $65 \mathrm{ppbv}$ (accounting for $22 \%$ of the summer days) and about 8 days with MDA 8 exceeding $70 \mathrm{ppbv}$, the current ozone air quality standard. However, if there were no wildfire emissions, the frequency of ozone exceedance days would significantly decrease. For the total exceedance days at the 13 sites in this period, the number with MDA8 above $65 \mathrm{ppbv}$ (above $70 \mathrm{ppbv}$ ) would decrease by $28 \%$ to 1509 days (by $31 \%$ to 474 days). This reduction is particularly important in high fire years such as 2002-2003 and 2005-2007 when one third to half of the exceedances would not occur without the fires. In total, wildfires contribute 28,31 , and $32 \%$ of the days when MDA8 ozone exceeds 65,70 , and $75 \mathrm{ppbv}$, 


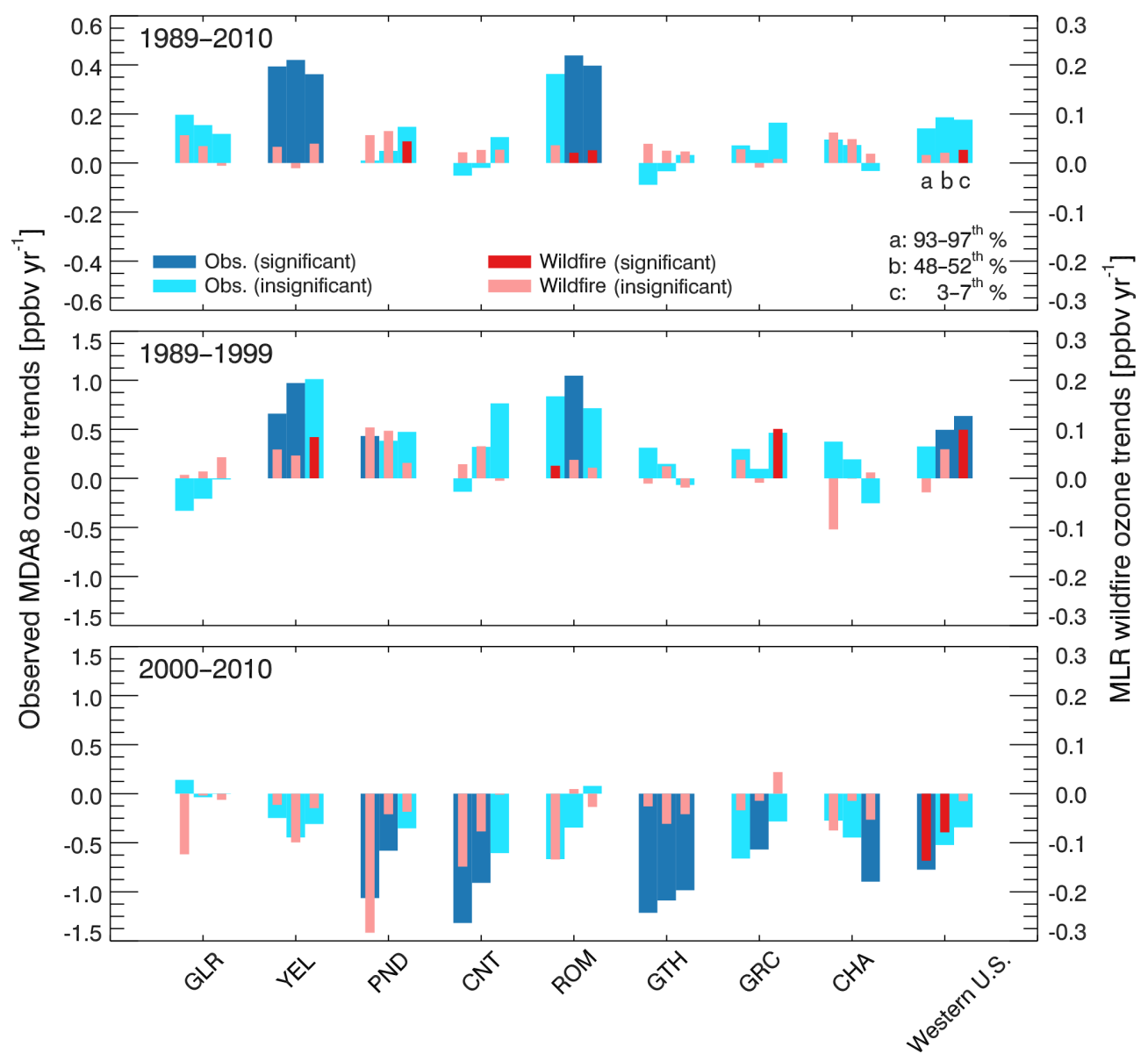

Figure 8. Linear trends of summer mean MDA8 ozone concentrations (blue bars, left axis) for 1989-2010 (top panel), 1989-1999 (middle panel), and 2000-2010 (bottom panel) at eight CASTNet sites and for the Intermountain West regional averages for the (a) 93-97th, (b) 48-52th, and (c) 3-7th percentile ranges. Also shown are the trends contributed by wildfire ozone enhancements (red bars, right axis) as computed by the MLR models. Statistically significant trends $(p<0.05)$ are emphasized in dark color.

respectively, reflecting small changes in the relative importance of wildfire influences as lowering the air quality standard over this region.

\section{Conclusions}

In this study, we have applied a new approach based on a Lagrangian particle dispersion model (FLEXPART) and statistical models to quantify the wildfire influences on the ozone daily and interannual variability, trends, and exceedance days over the US Intermountain West in the summers 1989-2010. The recent implementation of a more stringent ozone standard (70 ppbv) in the United States also motivates the need to better understand contributions and variations of natural ozone sources such as wildfires.

We introduce a FI, a measure of wildfires' impact at a receptor site, by using 5-day FLEXPART retroplumes (plumes of back-trajectory particles) combined with a daily highresolution wildfire burned area dataset in the western US.
The FI values are computed for each ozone measurement day in the summers 1989-2010 for the ensemble of 13 CASTNet sites and an urban site (SLC) over the US Intermountain West. We then develop statistical MLR models that estimate MDA8 ozone concentrations at each site as a function of FI and various meteorological variables. We show that the MLR models explain $60 \%$ (estimated for the ensemble of 13 CASTNet sites) of the variability of MDA8 ozone over the US Intermountain West (16-59\% at individual sites), which is comparable with results from current Eulerian CTMs $\left(R^{2}=0.25-0.48\right)$.

The MLR models allow us to diagnose the MDA8 ozone enhancements from wildfires as well as ozone controlled by meteorological variables. We compare wildfire ozone enhancements estimated by the MLR models with those from the GEOS-Chem CTM for summer 2007. While some consistency is found as reflected by their moderate correlations ( $r=0.34-0.48$, statistically significant $p<0.05$ ), the two methods show rather different patterns. The MLR method ap- 


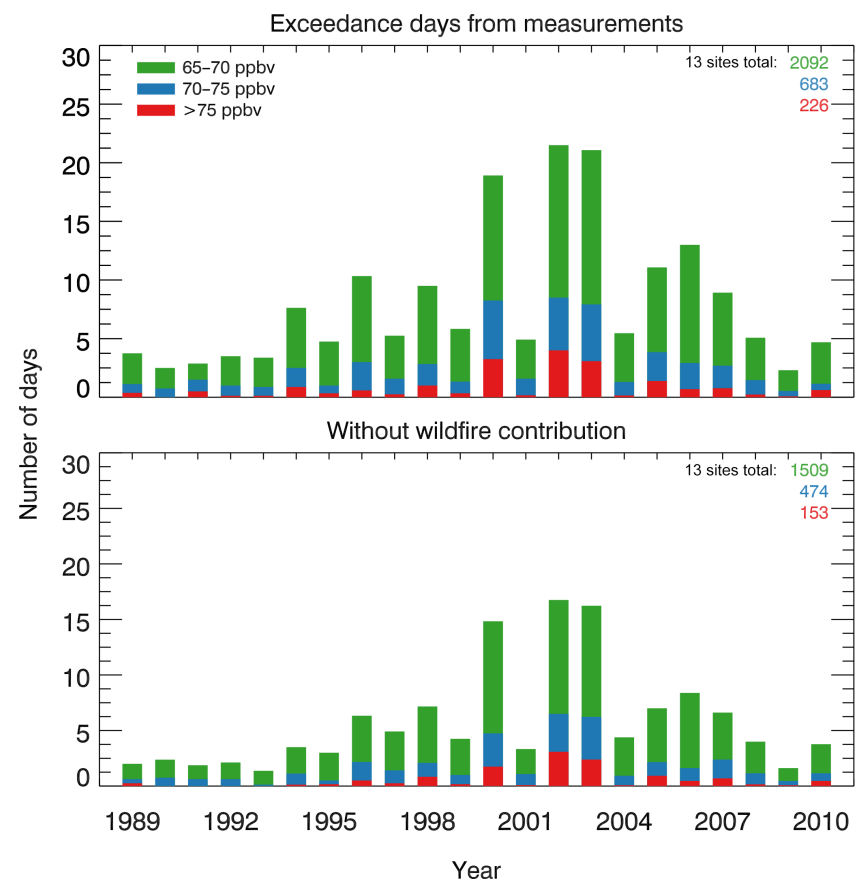

Figure 9. Mean number of days with MDA8 ozone concentrations exceeding the thresholds of 65,70 , and 75 ppbv averaged over the 13 CASTNet sites in the Intermountain West for the summers 1989-2010. The top panel shows the exceedances computed from the measurements, and the bottom panel shows results that would be presented in the absence of wildfires (measurements minus the MLR estimated wildfire ozone enhancements).

pears to better capture wildfire ozone influences at larger distances downwind of the fires or ozone produced from smallscale fires. We find that wildfire ozone enhancements estimated by the MLR models occasionally reach 10-20 ppbv at the Intermountain West CASTNet sites, and they tend to increase as measured ozone concentrations increase, reflecting higher wildfire impacts on the high-ozone days. Meteorological variations also show distinct impacts on both wildfire activities and MDA8 ozone concentrations. High wildfire events and high ozone days are often associated with high temperatures, strong solar radiation, and low RH and wind speed.

We find wildfires increase the summer mean MDA8 ozone concentrations by $0.3-1.5$ ppbv averaged over the Intermountain West CASTNet sites during 1989-2010. While the interannual variability of summer mean wildfire ozone enhancements is strongly correlated with that of the MLR total ozone, the wildfire-driven interannual variability is much weaker than the ozone variability that can be explained by meteorological parameters. We suggest that the strong interannual correlation between summer mean ozone concentrations and wildfire activities can be partly driven by their common relationships with meteorological parameters such as $\mathrm{RH}$ and temperature. These common relationships may also be responsible for the synchronous trends of summer mean surface MDA8 ozone concentrations and wildfire ozone enhancements for either the 1989-2010 period or two separated 11-year periods (1989-1999 vs. 2000-2010).

Wildfires thus present an important source affecting surface ozone air quality in the US Intermountain West. Despite small enhancements when averaged seasonally or regionally, they have notable impact on the occurrence of ozone exceedances, reflecting the small-scale and episodic nature of wildfire emissions. We show that about one third of the summer days (1989-2010) with MDA8 ozone exceeding $70 \mathrm{ppbv}$ would not occur in the absence of wildfires. A recent study by Brey and Fischer (2016) investigated fire impacts on ozone at urban sites over the contiguous US and found that fire ozone influences can be even higher at locations with high $\mathrm{NO}_{x}$ emissions. While we have shown that our Lagrangian and statistical approach provides a quantitative estimate of ozone enhancements from wildfires and can be applied to analyze long-term ozone records, there are still considerable uncertainties in this approach from both the FLEXPART calculation and the MLR models as discussed in the text. The approach also does not consider the complexity in fire emissions and cannot probe into the physical and chemical processes in the fire plumes. To address this issue would require more detailed fire plume measurements and finer-scale modeling approaches, such as imbedding a plume-in-grid model in CTMs.

\section{Data availability}

The datasets used in the study can be accessed from websites listed in the references or by contacting the corresponding author.

\section{The Supplement related to this article is available online at doi:10.5194/acp-16-14687-2016-supplement.}

Acknowledgements. This work was supported by China's National Basic Research Program (2014CB441303) and by the National Natural Science Foundation of China (41475112).

Edited by: Q. Zhang

Reviewed by: two anonymous referees

\section{References}

Air Quality System (AQS), data available at https://www3.epa.gov/ airdata/, 2015.

Akagi, S. K., Yokelson, R. J., Wiedinmyer, C., Alvarado, M. J., Reid, J. S., Karl, T., Crounse, J. D., and Wennberg, P. O.: Emission factors for open and domestic biomass burning for use 
in atmospheric models, Atmos. Chem. Phys., 11, 4039-4072, doi:10.5194/acp-11-4039-2011, 2011.

Alvarado, M. J., Logan, J. A., Mao, J., Apel, E., Riemer, D., Blake, D., Cohen, R. C., Min, K. E., Perring, A. E., Browne, E. C., Wooldridge, P. J., Diskin, G. S., Sachse, G. W., Fuelberg, H., Sessions, W. R., Harrigan, D. L., Huey, G., Liao, J., Case-Hanks, A., Jimenez, J. L., Cubison, M. J., Vay, S. A., Weinheimer, A. J., Knapp, D. J., Montzka, D. D., Flocke, F. M., Pollack, I. B., Wennberg, P. O., Kurten, A., Crounse, J., Clair, J. M. S., Wisthaler, A., Mikoviny, T., Yantosca, R. M., Carouge, C. C., and Le Sager, P.: Nitrogen oxides and PAN in plumes from boreal fires during ARCTAS-B and their impact on ozone: an integrated analysis of aircraft and satellite observations, Atmos. Chem. Phys., 10, 9739-9760, doi:10.5194/acp-10-9739-2010, 2010.

Andreae, M. O. and Merlet, P.: Emission of trace gases and aerosols from biomass burning, Global Biogeochem. Cy., 15, 955-966, 2001.

Baylon, P., Jaffe, D. A., Wigder, N. L., Gao, H., and Hee, J.: Ozone enhancement in western US wildfire plumes at the Mt. Bachelor Observatory: The role of $\mathrm{NO}_{x}$, Atmos. Environ., 109, 297-304, doi:10.1016/j.atmosenv.2014.09.013, 2014.

Bey, I., Jacob, D. J., Yantosca, R. M., Logan, J. A., Field, B. D., Fiore, A. M., Li, Q., Liu, H. Y., Mickley, L. J., and Schultz, M. G.: Global modeling of tropospheric chemistry with assimilated meteorology: Model description and evaluation, J. Geophys. Res.-Atmos., 106, 23073-23095, 2001.

Brey, S. J. and Fischer, E. V.: Smoke in the City: How Often and Where Does Smoke Impact Summertime Ozone in the United States?, Environ. Sci. Technol., 50, 1288-1294, 2016.

Camalier, L., Cox, W., and Dolwick, P.: The effects of meteorology on ozone in urban areas and their use in assessing ozone trends, Atmos. Environ., 41, 7127-7137, 2007.

Clean Air Status and Trends Network (CASTNET), data available at https://java.epa.gov/castnet/clearsession.do, 2015.

Cooper, O. R., Stohl, A., Eckhardt, S., Parrish D. D., Oltmans, S. J., Johnson, B. J., Nédélec, P., Schmidlin, F. J., Newchurch, M. J., Kondo, Y., and Kita, K.: A springtime comparison of tropospheric ozone and transport pathways on the east and west coasts of the United States, J. Geophys. Res., 110, D05S90, doi:10.1029/2004JD005183, 2005.

Cooper, O. R., Parrish, D. D., Stohl, A., Trainer, M., Nédélec, P., Thouret, V., Cammas, J. P., Oltmans, S. J., Johnson, B. J., Tarasick, D., Leblanc, T., McDermid, I. S., Jaffe, D., Gao, R., Stith, J., Ryerson, T., Aikin, K., Campos, T., Weinheimer, A., and Avery, M. A.: Increasing springtime ozone mixing ratios in the free troposphere over western North America, Nature, 463, 344-348, 2010.

Cooper, O. R., Gao, R., Tarasick, D., Leblanc, T., and Sweeney, C.: Long-term ozone trends at rural ozone monitoring sites across the United States, 1990-2010, J. Geophys. Res.-Atmos., 117, D22307, doi:10.1029/2012JD018261, 2012.

Cooper, O. R., Parrish, D. D., Ziemke, J., Balashov, N. V., Cupeiro, M., Galbally, I. E., Gilge, S., Horowitz, L., Jensen, N. R., Lamarque, J. F., Naik, V., Oltmans, S. J., Schwab, J., Shindell, D. T., Thompson, A. M., Thouret, V., Wang, Y., and Zbinden, R. M.: Global distribution and trends of tropospheric ozone: An observation-based review, Elementa: Science of the Anthropocene, 2, 000029, doi:10.12952/journal.elementa.000029, 2014.
Cooper, O. R., Langford, A. O., Parrish, D. D., and Fahey, D. W.: Challenges of a lowered US ozone standard, Science, 348, 10961097, 2015.

Doherty, R. M., Wild, O., Shindell, D. T., Zeng, G., MacKenzie, I. A., Collins, W. J., Fiore, A. M., Stevenson, D. S., Dentener, F. J., Schultz, M. G., Hess, P., Derwent, R. G., and Keating, T. J.: Impacts of climate change on surface ozone and intercontinental ozone pollution: A multi-model study, J. Geophys. Res.-Atmos., 118, 3744-3763, 2013.

Dolwick, P., Akhtar, F., Baker, K. R., Possiel, N., Simon, H., and Tonnesen, G.: Comparison of background ozone estimates over the western United States based on two separate model methodologies, Atmos. Environ., 109, 282-296, 2015.

Emery, C., Jung, J., Downey, N., Johnson, J., Jimenez, M., Yarwood, G., and Morris, R.: Regional and global modeling estimates of policy relevant background ozone over the United States, Atmos. Environ., 47, 206-217, 2012.

Field, A.: Discovering Statistics Using SPSS, 3rd Edn. ; Sage Publications: Thousand Oaks, CA, 2009.

Fiore, A. M., Jacob, D. J., Bey, I., Yantosca, R. M., Field, B. D., Fusco, A. C., and Wilkinson, J. G.: Background ozone over the United States in summer: Origin, trend, and contribution to pollution episodes, J. Geophys. Res., 107, D154275, doi:10.1029/2001JD000982, 2002.

Fiore, A. M., Dentener, F. J., Wild, O., Cuvelier, C., Schultz, M. G., Hess, P., Textor, C., Schulz, M., Doherty, R. M., Horowitz, L. W., MacKenzie, I. A., Sanderson, M. G., Shindell, D. T., Stevenson, D. S., Szopa, S., Van Dingenen, R., Zeng, G., Atherton, C., Bergmann, D., Bey, I., Carmichael, G., Collins, W. J., Duncan, B. N., Faluvegi, G., Folberth, G., Gauss, M., Gong, S., Hauglustaine, D., Holloway, T., Isaksen, I. S. A., Jacob, D. J., Jonson, J. E., Kaminski, J. W., Keating, T. J., Lupu, A., Marmer, E., Montanaro, V., Park, R. J., Pitari, G., Pringle, K. J., Pyle, J. A., Schroeder, S., Vivanco, M. G., Wind, P., Wojcik, G., Wu, S., and Zuber, A.: Multimodel estimates of intercontinental sourcereceptor relationships for ozone pollution, J. Geophys. Res., 114, D04301, doi:10.1029/2008JD010816, 2009.

Fiore, A. M., Oberman, J. T., Lin, M. Y., Zhang, L., Clifton, O. E., Jacob, D. J., Naik, V., Horowitz, L. W., Pinto, J. P., and Milly, G. P.: Estimating North American background ozone in US surface air with two independent global models: Variability, uncertainties, and recommendations, Atmos. Environ., 96, 284-300, 2014.

Fire and Aviation Management Web application system (FAMWEB), data available at https://fam.nwcg.gov/fam-web/, 2014.

Fischer, E. V., Jacob, D. J., Yantosca, R. M., Sulprizio, M. P., Millet, D. B., Mao, J., Paulot, F., Singh, H. B., Roiger, A., Ries, L., Talbot, R. W., Dzepina, K., and Pandey Deolal, S.: Atmospheric peroxyacetyl nitrate (PAN): a global budget and source attribution, Atmos. Chem. Phys., 14, 2679-2698, doi:10.5194/acp-142679-2014, 2014.

Grell, G., Freitas, S. R., Stuefer, M., and Fast, J.: Inclusion of biomass burning in WRF-Chem: impact of wildfires on weather forecasts, Atmos. Chem. Phys., 11, 5289-5303, doi:10.5194/acp11-5289-2011, 2011.

Interagency Monitoring of Protected Visual Environments (IMPROVE), data available at http://vista.cira.colostate.edu/ improve/, 2015. 
Jacob, D. J. and Winner, D. A.: Effect of climate change on air quality, Atmos. Environ., 43, 51-63, 2009.

Jaffe, D. and Ray, J.: Increase in surface ozone at rural sites in the western US, Atmos. Environ., 41, 5452-5463, 2007.

Jaffe, D., Chand, D., Hafner, W., Westerling, A., and Spracklen, D.: Influence of Fires on $\mathrm{O}_{3}$ Concentrations in the Western US, Environ. Sci. Technol., 42, 5885-5891, 2008.

Jaffe, D. A. and Wigder, N. L.: Ozone production from wildfires: A critical review, Atmos. Environ., 51, 1-10, 2012.

Jaffe, D. A., Wigder, N., Downey, N., Pfister, G., Boynard, A., and Reid, S. B.: Impact of Wildfires on Ozone Exceptional Events in the Western U. S., Environ. Sci. Technol., 47, 11065-11072, 2013.

Jiang, X., Wiedinmyer, C., and Carlton, A. G.: Aerosols from Fires: An Examination of the Effects on Ozone Photochemistry in the Western United States, Environ. Sci. Technol., 46, 11878-11886, 2012.

Koumoutsaris, S. and Bey, I.: Can a global model reproduce observed trends in summertime surface ozone levels?, Atmos. Chem. Phys., 12, 6983-6998, doi:10.5194/acp-12-6983-2012, 2012.

Lin, M., Fiore, A. M., Horowitz, L. W., Cooper, O. R., Naik, V., Holloway, J., Johnson, B. J., Middlebrook, A. M., Oltmans, S. J., Pollack, I. B., Ryerson, T. B., Warner, J. X., Wiedinmyer, C., Wilson, J., and Wyman, B.: Transport of Asian ozone pollution into surface air over the western United States in spring, J. Geophys. Res.-Atmos., 117, D00V07, doi:10.1029/2011JD016961, 2012a.

Lin, M., Fiore, A. M., Cooper, O. R., Horowitz, L. W., Langford, A. O., Levy, H., Johnson, B. J., Naik, V., Oltmans, S. J., and Senff, C. J.: Springtime high surface ozone events over the western United States: Quantifying the role of stratospheric intrusions, J. Geophys. Res.-Atmos., 117, D00V22, doi:10.1029/2012JD018151, 2012b.

Lin, M., Horowitz, L. W., Cooper, O. R., Tarasick, D., Conley, S., Iraci, L. T., Johnson, B., Leblanc, T., Petropavlovskikh, I., and Yates, E. L.: Revisiting the evidence of increasing springtime ozone mixing ratios in the free troposphere over western North America, Geophys. Res. Lett., 42, 8719-8728, 2015 a.

Lin, M., Fiore, A. M., Horowitz, L. W., Langford, A. O., Oltmans, S. J., Tarasick, D., and Rieder, H. E.: Climate variability modulates western US ozone air quality in spring via deep stratospheric intrusions, Nat. Commun., 6, 7105, doi:10.1038/ncomms8105, 2015b.

McDonald-Buller, E. C., Allen, D. T., Brown, N., Jacob, D. J., Jaffe, D., Kolb, C. E., Lefohn, A. S., Oltmans, S., Parrish, D. D., Yarwood, G., and Zhang, L.: Establishing Policy Relevant Background (PRB) Ozone Concentrations in the United States, Environ. Sci. Technol., 45, 9484-9497, 2011.

Monks, P. S., Archibald, A. T., Colette, A., Cooper, O., Coyle, M., Derwent, R., Fowler, D., Granier, C., Law, K. S., Mills, G. E., Stevenson, D. S., Tarasova, O., Thouret, V., von Schneidemesser, E., Sommariva, R., Wild, O., and Williams, M. L.: Tropospheric ozone and its precursors from the urban to the global scale from air quality to short-lived climate forcer, Atmos. Chem. Phys., 15, 8889-8973, doi:10.5194/acp-15-8889-2015, 2015.

Mueller, S. F. and Mallard, J. W.: Contributions of Natural Emissions to Ozone and $\mathrm{PM}_{2.5}$ as Simulated by the Community Mul- tiscale Air Quality (CMAQ) Model, Environ. Sci. Technol., 45, 4817-4823, 2011.

National Center for Environmental Prediction (NCEP) Climate Forecast System Reanalysis (CFSR), data available at http://rda. ucar.edu/pub/cfsr.html, 2014.

Park, R. J., Jacob, D. J., and Logan, J. A.: Fire and biofuel contributions to annual mean aerosol mass concentrations in the United States, Atmos. Environ., 41, 7389-7400, 2007.

Parrington, M., Palmer, P. I., Lewis, A. C., Lee, J. D., Rickard, A. R., Di Carlo, P., Taylor, J. W., Hopkins, J. R., Punjabi, S., Oram, D. E., Forster, G., Aruffo, E., Moller, S. J., Bauguitte, S. J.-B., Allan, J. D., Coe, H., and Leigh, R. J.: Ozone photochemistry in boreal biomass burning plumes, Atmos. Chem. Phys., 13, 73217341, doi:10.5194/acp-13-7321-2013, 2013.

Parrish, D. D., Lamarque, J. F., Naik, V., Horowitz, L., Shindell, D. T., Staehelin, J., Derwent, R., Cooper, O. R., Tanimoto, H., Volz-Thomas, A., Gilge, S., Scheel, H. E., Steinbacher, M., and Fröhlich, M.: Long-term changes in lower tropospheric baseline ozone concentrations: Comparing chemistry-climate models and observations at northern midlatitudes, J. Geophys. Res.-Atmos., 119, 5719-5736, 2014.

Pfister, G. G., Wiedinmyer, C., and Emmons, L. K.: Impacts of the fall 2007 California wildfires on surface ozone: Integrating local observations with global model simulations, Geophys. Res. Lett., 35, L19814, doi:10.1029/2008GL034747, 2008

Pusede, S. E., Steiner, A. L., and Cohen, R. C.: Temperature and Recent Trends in the Chemistry of Continental Surface Ozone, Chem. Rev., 115, 3898-3918, 2015.

Rasmussen, D. J., Fiore, A. M., Naik, V., Horowitz, L. W., McGinnis, S. J., and Schultz, M. G.: Surface ozone-temperature relationships in the eastern US: A monthly climatology for evaluating chemistry-climate models, Atmos. Environ., 47, 142-153, 2012.

Real, E., Law, K. S., Weinzierl, B., Fiebig, M., Petzold, A., Wild, O., Methven, J., Arnold, S., Stohl, A., Huntrieser, H., Roiger, A., Schlager, H., Stewart, D., Avery, M., Sachse, G., Browell, E., Ferrare, R., and Blake, D.: Processes influencing ozone levels in Alaskan forest fire plumes during long-range transport over the North Atlantic, J. Geophys. Res., 112, D10S41, doi:10.1029/2006JD007576, 2007.

Seibert, P. and Frank, A.: Source-receptor matrix calculation with a Lagrangian particle dispersion model in backward mode, Atmos. Chem. Phys., 4, 51-63, doi:10.5194/acp-4-51-2004, 2004.

Shindell, D. T., Lamarque, J. F., Schulz, M., Flanner, M., Jiao, C., Chin, M., Young, P. J., Lee, Y. H., Rotstayn, L., Mahowald, N., Milly, G., Faluvegi, G., Balkanski, Y., Collins, W. J., Conley, A. J., Dalsoren, S., Easter, R., Ghan, S., Horowitz, L., Liu, X., Myhre, G., Nagashima, T., Naik, V., Rumbold, S. T., Skeie, R., Sudo, K., Szopa, S., Takemura, T., Voulgarakis, A., Yoon, J. H., and Lo, F.: Radiative forcing in the ACCMIP historical and future climate simulations, Atmos. Chem. Phys., 13, 2939-2974, doi:10.5194/acp-13-2939-2013, 2013.

Simon, H., Reff, A., Wells, B., Xing, J., and Frank, N.: Ozone Trends Across the United States over a Period of Decreasing NOx and VOC Emissions, Environ. Sci. Technol., 49, 186-195, 2015.

Singh, H. B., Cai, C., Kaduwela, A., Weinheimer, A., and Wisthaler, A.: Interactions of fire emissions and urban pollution over Cali- 
fornia: Ozone formation and air quality simulations, Atmos. Environ., 56, 45-51, 2012.

Sofiev, M., Vankevich, R., Ermakova, T., and Hakkarainen, J.: Global mapping of maximum emission heights and resulting vertical profiles of wildfire emissions, Atmos. Chem. Phys., 13, 7039-7052, doi:10.5194/acp-13-7039-2013, 2013.

Spracklen, D. V., Logan, J. A., Mickley, L. J., Park, R. J., Yevich, R., Westerling, A. L., and Jaffe, D. A.: Wildfires drive interannual variability of organic carbon aerosol in the western US in summer, Geophys. Res. Lett., 34, L16816, doi:10.1029/2007GL030037, 2007.

Stevenson, D. S., Young, P. J., Naik, V., Lamarque, J. F., Shindell, D. T., Voulgarakis, A., Skeie, R. B., Dalsoren, S. B., Myhre, G., Berntsen, T. K., Folberth, G. A., Rumbold, S. T., Collins, W. J., MacKenzie, I. A., Doherty, R. M., Zeng, G., van Noije, T. P. C., Strunk, A., Bergmann, D., Cameron-Smith, P., Plummer, D. A., Strode, S. A., Horowitz, L., Lee, Y. H., Szopa, S., Sudo, K., Nagashima, T., Josse, B., Cionni, I., Righi, M., Eyring, V., Conley, A., Bowman, K. W., Wild, O., and Archibald, A.: Tropospheric ozone changes, radiative forcing and attribution to emissions in the Atmospheric Chemistry and Climate Model Intercomparison Project (ACCMIP), Atmos. Chem. Phys., 13, 3063-3085, doi:10.5194/acp-13-3063-2013, 2013.

Stocker, T. F., Qin, D. ; Plattner, G. -K., Tignor, M., Allen, S. K., Boschung, J., Nauels, A., Xia, Y., Bex, V., and Midgley, P. M.: IPCC, 2013: Climate change 2013: The physical science basis. Contribution of working group I to the fourth assessment report of the intergovernmental panel on climate change; Cambridge University Press, Cambridge, United Kingdom and New York, NY, USA, 2013.

Stohl, A., Forster, C., Eckhardt, S., Spichtinger, N., Huntrieser, H., Heland, J., Schlager, H., Wilhelm, S., Arnold, F., and Cooper, O.: A backward modeling study of intercontinental pollution transport using aircraft measurements, J. Geophys. Res., 108, D124370, doi:10.1029/2002JD002862, 2003.

Stohl, A., Forster, C., Frank, A., Seibert, P., and Wotawa, G.: Technical note: The Lagrangian particle dispersion model FLEXPART version 6. 2, Atmos. Chem. Phys., 5, 2461-2474, doi:10.5194/acp-5-2461-2005, 2005.

Stohl, A., Seibert, P., Wotawa, G., Arnold, D., Burkhart, J. F., Eckhardt, S., Tapia, C., Vargas, A., and Yasunari, T. J.: Xenon133 and caesium-137 releases into the atmosphere from the Fukushima Dai-ichi nuclear power plant: determination of the source term, atmospheric dispersion, and deposition, Atmos. Chem. Phys., 12, 2313-2343, doi:10.5194/acp-12-2313-2012, 2012.
Strode, S. A., Rodriguez, J. M., Logan, J. A., Cooper, O. R., Witte, J. C., Lamsal, L. N., Damon, M., Van Aartsen, B., Steenrod, S. D., and Strahan, S. E.: Trends and variability in surface ozone over the United States, J. Geophys. Res.-Atmos., 120, 9020-9042, 2015.

Tai, A. P. K., Mickley, L. J., and Jacob, D. J.: Correlations between fine particulate matter $\left(\mathrm{PM}_{2.5}\right)$ and meteorological variables in the United States: Implications for the sensitivity of $\mathrm{PM}_{2.5}$ to climate change, Atmos. Environ., 44, 3976-3984, 2010.

Tai, A. P. K., Mickley, L. J., Jacob, D. J., Leibensperger, E. M., Zhang, L., Fisher, J. A., and Pye, H. O. T.: Meteorological modes of variability for fine particulate matter $\left(\mathrm{PM}_{2.5}\right)$ air quality in the United States: implications for $\mathrm{PM}_{2.5}$ sensitivity to climate change, Atmos. Chem. Phys., 12, 3131-3145, doi:10.5194/acp12-3131-2012, 2012.

US Environmental Protection Agency: Air Quality Criteria for Ozone and Related Photochemical Oxidants (Final), Vols. I, II, and III, EPA 600/R-05/004aF-cF, 2006.

US Environmental Protection Agency: National ambient air quality standards for ozone, Fed. Regist., 80, 65292-65468, 2015.

Val Martin, M., Logan, J. A., Kahn, R. A., Leung, F. -Y., Nelson, D. L., and Diner, D. J.: Smoke injection heights from fires in North America: analysis of 5 years of satellite observations, Atmos. Chem. Phys., 10, 1491-1510, doi:10.5194/acp-10-14912010, 2010.

Westerling, A. L., Hidalgo, H. G., Cayan, D. R., and Swetnam, T. W.: Warming and Earlier Spring Increase Western US Forest Wildfire Activity, Science, 313, 940-943, 2006.

Yue, X., Mickley, L. J., Logan, J. A., and Kaplan, J. O.: Ensemble projections of wildfire activity and carbonaceous aerosol concentrations over the western United States in the mid-21st century, Atmos. Environ., 77, 767-780, 2013.

Zhang, L., Jacob, D. J., Kopacz, M., Henze, D. K., Singh, K., and Jaffe, D. A.: Intercontinental source attribution of ozone pollution at western US sites using an adjoint method, Geophys. Res. Lett., 36, L11810, doi:10.1029/2009GL037950, 2009.

Zhang, L., Jacob, D. J., Downey, N. V., Wood, D. A., Blewitt, D., Carouge, C. C., van Donkelaar, A., Jones, D. B. A., Murray, L. T., and Wang, Y.: Improved estimate of the policy-relevant background ozone in the United States using the GEOS-Chem global model with $1 / 2^{\circ} \times 2 / 3^{\circ}$ horizontal resolution over North America, Atmos. Environ., 45, 6769-6776, 2011.

Zhang, L., Jacob, D. J., Yue, X., Downey, N. V., Wood, D. A., and Blewitt, D.: Sources contributing to background surface ozone in the US Intermountain West, Atmos. Chem. Phys., 14, 52955309, doi:10.5194/acp-14-5295-2014, 2014. 